\title{
APLINKYBINIAI ANTRINIAI PREDIKATYVAI LIETUVIŲ KALBOJE
}

\author{
Veslava ČIŽlK-PROKAŠEVA \\ Lietuvių kalbos institutas
}

\section{Ivadas}

Laisvieji antriniai predikatyvai užsienio ir lietuvių kalbotyroje jau nemažai tyrinèti. Paprastai jie skirstomi ị rezultatinius ir nerezultatinius antrinius predikatyvus. Nerezultatiniai antriniai predikatyvai kai kurių kalbininkų savo ruožtu skirstomi ị depiktyvus ir aplinkybinius antrinius predikatyvus ${ }^{1}$. Axelis Holvoetas, Rolandas Mikulskas (žr. Holvoet 2003; Holvoet, Tamulionienė 2005; Holvoet, Mikulskas [A], [B]; Mikulskas 2009), Loreta Vaičiulytė-Seménienè (2007a, 2007b, 2010, 2012a, 2012b, 2014) savo straipsniuose daugiausia dèmesio skyrè probleminiams ribų tarp atskirų predikatyvų tipų (ar aplinkybių) atvejams. Veslava Čižik-Prokaševa aprašè antrinių predikatyvų sampratos formavimąsi, jų klasifikacijas lietuvių ir užsienio kalbotyroje, depiktyvų žymèjimą lietuvių kalboje, laisvųjų antrinių predikatyvų vietą sakinyje, nustate preliminarų lietuvių kalbos laisvųjų predikatyvų semantinị žemėlapi (2010a, 2010b, 2011a, 2011b, 2012). Tačiau lietuviu kalbos aplinkybiniams predikatyvams nebuvo skirta pakankamai dėmesio. Visų pirma, aplinkybiniai antriniai predikatyvai buvo aptariami kartu su depiktyvais. Antra, nei vienas iš anksčiau minètų darbų neapima aplinkybinių antrinių predikatyvų morfosintaksès visumos. Šis straipsnis skirtas aprašyti vien lietuvių kalbos aplinkybinius antrinius predikatyvus. Jame bus trumpai aptarti ju panašumai ir skirtumai su kitais antriniais predikatyvais (straipsnio antra dalis), aplinkybinių antrinių predikatyvų reikšmès (trečia dalis), aplinkybinių antrinių predikatyvų žymèjimas lietuvių kalboje (ketvirta dalis) ir jų vieta sakinyje (penkta dalis). Siekiant aprašyti aplinkybinių antrinių predikatyvų morfosintaksinę visumą, straipsnio trečioje ir ketvirtoje dalyje pateikiama daug pavyzdžių, kiekvienu konkrečiu atveju norima parodyti visų rastų pavyzdžių įvairovę ir skirtingas žymejjimo galimybes. Apibendrinimai bus pateikti paskutinèje straipsnio dalyje. Bus siekiama parodyti, ar lietuvių kalbos aplinkybiniai antriniai predikatyvai skiriasi nuo kitų antrinių predikatyvų, ir papildyti duomenis, pateiktus lietuvių kalbos gramatikose ir sintaksés tyrimuose.

Buvo surinkti 473 aplinkybinių antrinių predikatyvų pavyzdžiai. Jie buvo renkami iš Jono Jablonskio Linksnių ir prielinksniu, Jono Balkevičiaus Dabartinès lietuvių kalbos sintaksès, Adelès Valeckienès 1967 metų straipsnio,

1 Apie sąvokų antrinis predikatyvas, laisvasis (rezultatinis / nerezultatinis) antrinis predikatyvas sampratą žr. Čižik-Prokaševa 2010b. 
Lietuviu kalbos gramatikos, Vito Labučio Lietuvių kalbos sintaksès ir 1992 metu straipsnio, Dabartinès lietuviu kalbos gramatikos, Julijos Žukauskaitès 1961 metų straipsnio, Jono Šukio knygos Lietuvių kalbos linksniai ir prielinksniai: vartosena ir normos, Axelio Holvoeto su bendraautoriais, Loretos VaičiulytėsSemėnienės bei užsienio kalbininkų straipsnių, kuriuose aptariama antrinių predikatyvų tematika, iš Kauno VDU Kompiuterinès lingvistikos centro sudaryto Dabartinés lietuvių kalbos tekstyno (prieiga internete http://donelaitis. vdu.lt, toliau DLKT), iš Lietuviǔ kalbos žodyno (prieiga internete www.lkz.lt, elektroninis leidimas, toliau LKŽe). Yra ir pavyzdžių, rastų naudojant interneto paieškos sistemą Google (prieiga internete http://www.google.lt). Kiekvienas pavyzdys turi atitinkamą nuorodą. Keli pavyzdžiai yra straipsnio autoriaus, straipsnyje jie pateikti be nuorodos.

\section{Aplinkybinių antrinių predikatyvų samprata}

Joanna Nichols aplinkybinius antrinius predikatyvus vadino distinctive free predicate nominals. Ji rašè, kad šios grupès predikatyvai „,nerodo, kokios būklès yra pagrindinės predikacijos argumentas tuo metu, kai vyksta veiksmas, o tik konstatuoja, kad veiksmas vyksta kai, jei, nors, net jei pagrindinès predikacijos argumentas yra vienokios ar kitokios būklès" (Nichols 1978b: 116). Pateikiamas toks pavyzdys:

(1) Rebenkom on žil v Pariže. / As a child he lived in Paris. ,Būdamas vaikas jis gyveno Paryžiuje،

Toliau J. Nichols skiria tris šios grupès tipus, nurodydama, kad jie atitinka tradicinius aplinkybių tipus: laiko (angl. temporal) (žr. sakinị 2), nuolaidos (angl. concessive) (žr. sakinị 3), ir sąlygos (angl. conditional)2 (̌̌r. sakinị 4):

(2) I knew him young. / Ja znal ego molodym. (Nichols 1978b: 115) ,Pažinojau ji jauną،

(3) Even dead I won't forget. / Ja i mertvyj ne zabudu. (ten pat) ,Nepamiršiu to net miręs"

(4) I can't work hungry. / Golodnyi ja ne mogu rabotat'. (ten pat) ,Alkanas negaliu dirbti"

Monica-Alexandrina Irimia skyre ne tik aplinkybinius antrinius predikatyvus (angl. circumstantials), bet ir absoliučiuosius antrinius predikatyvus (angl. absolutes). Autorés nuomone, aplinkybiniai (žr. sakinį 5) ir absoliutieji

2 Vèlesniame darbe J. Nichols irgi skiria tris aplinkybinių predikatyvų tipus, tačiau prie sąlygos aplinkybinių predikatyvų pateikia ir priežasties reikšmės aplinkybinius predikatyvus (žr. Nichols 1981: 137). 
(žr. sakinį 6) antriniai predikatyvai - sintaksiškai yra nepriklausomi ${ }^{3}$ (angl. syntactically independent), modifikavimo ryšiu su predikatu susiję laisvieji nurodymai (angl. adjunct), jie niekada nebūna rezultatiniai ir teikia tik papildomos informacijos (žr. Irimia 2005: 24). Aplinkybinius antrinius predikatus, jos nuomone, sudaro sintaksiškai savarankiški žodžiai, o absoliučiuosius - sakiniai. Autorè pateikia tokius anglu kalbos pavyzdžius:

(5) He didn't leave, outraged. / Outraged, he didn't leave. (Irimia 2005: 24) ,Jis neišèjo pasipiktinęs"

(6) They got off the plane, their hands full of dust. (ten pat), Jie išlipo iš lèktuvo dulkinom rankom"

M.-A. Irimia skyrè tris aplinkybinių ir absoliučiųjų antrinių predikatyvų tipus: priežasties, laiko ir nuolaidos (žr. ten pat). Pavyzdžių nepateikia.

Nikolaus P. Himmelmannas ir Eva Schultze-Berndt (2005: 4tt) skiria tik du antriniu predikatyvu tipus: rezultatyvus ir depiktyvus (depiktyvai ju suprantami plačiąja prasme, įtraukiant ir aplinkybinius antrinius predikatyvus (angl. circumstantial or conditional secondary predicates; žr. ten pat: 15tt). Aplinkybiniai antriniai predikatyvai, jų nuomone, morfologiškai paprastai nesiskiria nuo depiktyvų siaurąa prasme ${ }^{4}$, tačiau skiriasi kitais kriterijais:

(a) semantika: aplinkybiniai antriniai predikatyvai teikia papildomas semantines (sąlygos, nuolaidos, laiko) nuorodas;

(b) santykiu su sakinio aktualiąja skaida: depiktyvai eina sakinio rema, perteikia pagrindinę sakinio informaciją (angl. focus), o aplinkybiniai antriniai predikatyvai - ne, kas paaiškina jų vietos sakinyje ir prozodijos skirtumus (daugiau apie tai žr. Halliday 1967: 65; Winkler 1997: 299tt);

(c) neigimo apréptimi: aplinkybiniai antriniai predikatyvai neįeina i pagrindiniu predikatu reiškiamo veiksmo neigimo aprẻptị: paneigus pagrindini predikatą toks antrinis predikatyvas lieka nepaneigtas (angl. outside the scope of negation), pvz.: Jam kaip mokiniui nederejo taip elgtis su direktoriumi, pagrindinis predikatas yra neigiamas, bet neigimas neapima predikatyvo - faktas, kad kažkas yra mokinys, lieka nepaneigtas (daugiau apie tai žr. Nichols 1978b: 121, 1981: 135; Himmelmann, Schultze-Berndt 2005: 17t; Schultze-Berndt, Himmelmann 2004: 68t; Vaičiulytė-Seménienė

3 „The real adjuncts are the circumstantials and absolutes; they behave syntactically independent, as they can easily move to different positions in the clause" (Irimia 2005: 20).

4 Plg.: „Being participant-oriented adjuncts, depictives and circumstantials are not clearly distinguishable in many languages“ (Šarić 2008a: 307). 
2007a: 90, 2007b: 117; Šarić 2008a: 308; Hentschel 2008: 99t; Holvoet, Mikulskas [B]: 7) ${ }^{5}$;

(d) itraukimu i pagrindinio sakinio predikaciją: jei predikatyvas yra pagrindinès predikacijos dalis (priklauso branduoliui), kaip sakinyje George usually drives home drunk ,Džordžas paprastai grịžta namo girtas', tai jis yra tikrasis depiktyvas (siaurąja prasme). Jeigu predikatyvas atlieka restriktyvinę funkciją, kaip sakinyje Drunk, George drives very dangerously ,Džordžas girtas vairuoja labai pavojingai“, kuriame drunk susiaurina pagrindinès predikacijos aprépti, t. y. nurodo, kad pavojingai vairuojama tik išgèrus, tai jis yra aplinkybinis. Autoriai nurodo, kad ir tikrieji depiktyvai, ir aplinkybiniai antriniai predikatyvai gali sudaryti vieną kategoriją. Todèl literatūroje dažniausiai ir skiriami tik depiktyvai (plačiąja prasme) ir rezultatyvai (žr. Himmelmann, Schultze-Berndt 2005: 15tt, 22t).

J. Nichols nuomone, depiktyvai ir aplinkybiniai predikatyvai vieni nuo kitu skiriasi ir parafrazių atžvilgiu. Aplinkybiniai antriniai predikatyvai perfrazuojami atitinkamos reikšmès (laiko, sąlygos, priežasties ir pan.) šalutiniu sakinio dẻmeniu, pagrindiniame sakinyje išlaikant pagrindini sakinio predikatą, plg., Būdamas mažas Jonukas ganè gyvulius; Jonukas ganè gyvulius, kai buvo mažas). O depiktyviniai predikatyvai perfrazuojami sudètiniu sakiniu, kurio pagrindinis predikatas vartojamas šalutiniame dėmenyje. Kitaip sakant, perfrazuojant depiktyvinius predikatyvus yra kas nors teigiama (angl. asserted) apie vieną iš situacijos dalyviu, o perfrazuojant aplinkybinius predikatyvus presuponuojama (angl. presupposed) (žr. Nichols 1981: 40). Be to, aplinkybinius antrinius predikatyvus nuo būtinųjų predikatyvų ir depiktyvų padeda skirti, kaip nurodo autoré, ir jų vartojimas greta kitų antrinių predikatyvų, kas nebūdinga kitiems predikatyvams. Taigi viename sakinyje, jos nuomone, gali būti pavartotas tik vienas aplinkybinis ir vienas neaplinkybinis depiktyvas (žr. sakinius 7, 8) arba keli skirtingų tipų aplinkybiniai predikatyvai (žr. sakinį 9)6, kas, jos nuomone, rodo labiau predikatyvų semantinị panašumą / skirtumą negu skirtingus sintaksinius santykius?:

5 Depiktyvams siaurąa prasme, skirtingai nei aplinkybiniams antriniams predikatyvams, tai nebūdinga. Paneigtą sakinị su depiktyvu galima interpretuoti dviem būdais: (a) paneigiamas pagrindinis predikatas ir depiktyvas, pvz., J. Bogatas buvo kažkur išejęs ir negrįzo patenkintas. (t. y. jis visai negrižo), arba (b) paneigiamas tik depiktyvas, pvz., J. Bogatas buvo kažkur išęęs ir negrįzo patenkintas. (t. y. jis grižzo liūdnas ir nepatenkintas).

6 Reikètu pridurti, kad savo vèlesniame darbe ji itterpia pastabą, kad du, bet tik to paties tipo, neaplinkybiniai antriniai predikatyvai galètų būti pavartoti sakinyje, jeigu jie tarpusavy susiję sujungiamuoju ryšiu, t. y. yra vienarūšès sakinio dalys (žr. Nichols 1981: 17tt).

7 ,...the co-occurrence test evidently distinguishes sameness vs. difference of semantic, rather than syntactic, relations“ (Nichols 1981: 19). 
(7) As a student (aplinkybinis) he worked as a waiter (būtinasis). (Nichols 1978b: 117) ,Būdamas studentas jis dirbo padaveju“

(8) As a student (aplinkybinis) he often came home from classes drunk (depiktyvas). (ten pat) ,Būdamas studentas jis dažnai grịždavo po paskaitu girtas

(9) As a student (laiko aplinkybinis predikatyvas) she always helped her friends even tired (nuolaidos aplinkybinis predikatyvas) (ten pat). ,Būdama studente ji net pavargusi visada padẻdavo savo draugams“

Gerdas Hentschelis irgi skiria aplinkybinius antrinius predikatyvus. Juos suskirsto ị tris tipus: laiko (angl. temporal-circumstantials) (žr. sakinị 10), sąlygos (angl. conditional-circumstantials) (̌̌r. sakinị 11) ir priežasties (angl. causal-circumstantials; pastarieji, jo nuomone, apima ir nuolaidos aplinkybinius antrinius predikatyvus) (žr. sakinị 12):

(10) Als Kind verlor er beide Beine. ,Vaikas jis neteko abiejų kojų

(11) Als Mittelstürmer spielt er gut. ,Kaip vidurio puolejjas jis žaidžia gerai‘

(12) Peter als Arbeitsloser bekam eine Ermäßigung. ,Petras kaip bedarbis gavo nuolaidą،

Depiktyvus ir aplinkybinius antrinius predikatyvus, jo nuomone, vienija jų orientacija ì pagrindinès predikacijos argumentą. Jie skiriasi tuo, kad depiktyvai įeina į veiksmažodinès frazès sudètį, o aplinkybiniai antriniai predikatyvai susiję su sakinio lygmeniu (vok. VP-externe, žr. Hentschel 2008: 121). Dar Hentschelis nurodo tokius pagrindinius depiktyvu ir aplinkybinių antrinių predikatyvų skirtumus: depiktyvai ịeina ị pagrindiniu predikatu reiškiamo veiksmo neigimo bei laiko ir modalumo aprépti, t. y. depiktyvai, skirtingai nei aplinkybiniai antriniai predikatyvai, neturi nepriklausomų laiko ir modalumo požymių (plačiau žr. Hentschel 2008: 98t, 113tt).

Sekdami užsienio kalbotyros tradicija, Axelis Holvoetas ir Rolandas Mikulskas pagal ịtraukimo ị pagrindinio sakinio predikaciją laipsnị laisvuosius antrinius predikatyvus skirsto ị depiktyvus ir aplinkybinius predikatyvus. Pastaruosius jie vadina propoziciniais antriniais predikatyvais ${ }^{8}$ ir pateikia tokius jų pavyzdžius:

8 Jų nuomone, aplinkybinių antrinių predikatyvų terminas nėra tinkamas, ,,nes jis nepabrèžia to, kas svarbiausia priešinant kalbamuosius antrinius predikatyvus kitiems laisviesiems antriniams predikatyvams“ (Holvoet, Mikulskas [B]: 7). A. Holvoetas ir R. Mikulskas visą sakinį modifikuojančius predikatyvus vadina propoziciniais dèl to, kad jų raiškoje įžvelgia savarankiškos predikacijos (modifikaciniu ryšiu susijusios su pagrindinès predikacijos teikiama propozicija) ypatybių (žr. Holvoet, Mikulskas [B]: 8). Bet iš tikrųių būtent šių antrinių predikatyvų semantinès sąlygos, nuolaidos, laiko ir priežasties nuorodos, kurios suartina juos su aplinkybėmis, ir atskiria šiuos antrinius predikatyvus nuo depiktyvų ir rezultatinių antrinių predikatyvų. Todèl aplinkybinio antrinio predikatyvo terminas atrodo kaip tik tinkamas. 
(13) Stipriai įsižeidęs, jis net nenuejo draugo pasveikinti su gimtadieniu.

(14) Jonui, kaip savo geriausiam draugui, negalejjau to dalyko nepasakyti. (Holvoet, Mikulskas [B]: 6)

Autoriai nurodo, kad propoziciniai antriniai predikatyvai skiriasi nuo depiktyviniu predikatyvų tik tuo, kad modifikuoja visą sakinį (visą sakiniu reiškiamą propoziciją), o ne vien sakinio predikatą ${ }^{9}$ Be to, semantiškai jie yra labiau orientuoti ị patị predikatu žymimą icvykị ${ }^{10}$, dèl to jų predikacija tik papildo pagrindinę sakinio predikaciją, bet nèra sudedamoji jos dalis (skirtingai nei depiktyvai, kurie yra įtraukiami ị pagrindinès predikacijos aprépti). Kita vertus, jų derinimas rodo, kad panašiai kaip ir depiktyvai, jie bent formaliai orientuoti i̇ vieną iš pagrindinès predikacijos argumentų ${ }^{11}$ (žr. Holvoet, Mikulskas [B]: 6tt; Mikulskas 2007: 124t). Taip pat autoriai nurodo, kad propozicinių antrinių predikatyvų reiškiamą papildomą predikaciją su pagrindinės predikacijos profiliuojamu ịvykiu paprastai sieja priežastinis (rečiau tikslo, nuolaidos ar laiko) ryšys (Holvoet, Mikulskas [B]: 6). Pateikta tik pora priežasties aplinkybinių antrinių predikatyvų pavyzdžiu bei pora nuolaidos ir laiko, o tikslo - nepateikta.

Panašiai laisvuosius aplinkybinius predikatyvus suvokia Loreta VaičiulytėSemėniené: ,aplinkybiniai predikatyvai, panašiai kaip depiktyvai, nėra rezultatyvai, bet, skirtingai nei depiktyvai, neįeina į pagrindiniu predikatu reiškiamo veiksmo neigimo aprépti (t. y. neigiamas pagrindinis predikatas, bet ne pats predikatyvas); jie yra sakinio, o ne veiksmažodinès frazès, dalis“ (VaičiulytėSemėnienė 2007a:90). Autorè nurodo, kad daiktavardžio kaip konstrukcijomis gali būti žymimi aplinkybiniai (laiko, nuolaidos, sąlygos, tikslo, priežasties) predikatyvai, tačiau pateikia tik kelis pavyzdžius.

Šiame darbe irgi laikomasi naujesnių pažiūrų, t. y. manoma, kad antriniai predikatyvai sudaro ne predikatinio (tarininio) pažyminio arba papildomo tarinio dalį ${ }^{12}$ o atskirą sakinio lygmens dalį; sintaksiškai jie priklauso tik nuo

9 J. Nichols taip pat mano, kad aplinkybiniai antriniai predikatyvai tiesiogiai priklauso ne nuo veiksmažodžio, o nuo viso sakinio ar (galbūt) nuo veiksmažodinės frazės (veiksmažodžio ir jo komplementų) (žr. Nichols 1978b: 126).

${ }_{10}$ Dar apie tai plg. Hentschel 2008.

11 Autoriai rašo, kad predikatyvo derinimas su pagrindinès predikacijos argumentu kalbamuoju atveju tetarnauja dviems skirtingoms propozicijoms priklausančių vardažodžių koreferentiškumui, o ne semantinio specifikavimo ryšiui nurodyti (žr. Holvoet, Mikulskas [B]: 8).

${ }^{12}$ Laisvųju antrinių predikatyvų traktavimas (ir tolimesnis skirstymas) tradicinejje lietuvių kalbotyroje priklauso nuo to, kas yra jais reiškiamos ypatybès turètojas. Jeigu predikatyvu reiškiama veiksnio ypatybe ir jis žymimas būdvardžio vardininku (veiksnio antrinis predikatyvas), tai jis vadinamas tarinio vardininku (žr. Jablonskis 1928/1957: 558), sudurtiniu tariniu (žr. Balkevičius 1963: 120tt), papildomu tariniu (žr. Labutis 1998: 248tt), predikatiniu, tarininiu arba predikatyviniu pažyminiu (žr. Ulvydas, red., 1976: 437tt; Ambrazas, red., 1996: 490t, 627; Valeckienė 1967: 105tt; Morkūnas, sud., Ambrazas, red., 2008: 536t). Papildinio ypatybę pasakantis antrinis predikatyvas vadinamas antrininkès tarinio dalies galininku (žr. Jablonskis 1928/1957: 
pagrindinio veiksmažodžio, o semantiškai susiję su vienu iš pagrindinio veiksmažodžio argumentų.

\section{Aplinkybinių antrinių predikatyvų reikšmès lietuvių kalboje}

Kaip jau buvo minėta 2 skyriuje, dažniausiai užsienio kalbininkų skiriamos trys aplinkybinių antrinių predikatyvų reikšmès: J. Nichols skiria laiko, nuolaidos, sąlygos, M.-A. Irimia - laiko, priežasties, nuolaidos, N. P. Himmelmannas ir E. Schultze-Berndt - sąlygos, nuolaidos, laiko, G. Hentschelis - laiko, sąlygos, priežasties. Lietuvių kalbininkai linkę skirti daugiau aplinkybinių antrinių predikatyvų reikšmių, tačiau pateikia tik po porą jų pavyzdžių.

\subsection{Laiko aplinkybiniai antriniai predikatyvai}

Daugiausia buvo surinkta laiko aplinkybinių antrinių predikatyvų: 196 pavyzdžiai (jie sudaro 41,4 \% visų aptariamų pavyzdžių). Visi šie aplinkybiniai predikatyvai perfrazuojami šalutiniais laiko sakiniais ir nurodo tam tikrus, apibrežtus laiko santykius. Dažniausiai jie yra derinami linksniu, skaičiumi ir gimine su pagrindinès predikacijos argumentu (tai gali būti subjektas, naudininko, galininko ir įnagininko objektas), ị kurị yra orientuoti (žr. sakinius 15-21), kartais tik skaičiumi ir gimine (žr. sakinị 22), o kartais yra reiškiami kitokiu linksniu nei pagrindinės predikacijos argumentas (žr. sakinị 20) arba yra reiškiami nelinksniuojama forma (žr. sakinị 23):

(15) Sušilę (= kai sušilsime) mes toliau keliausim. (Ulvydas, red., 1976:533)

(16) I puoda ippilti šalto vandens, įdèti vyniotini, pridèti prieskoniu ir virti apie 40 minučių ant silpnos ugnies. Išvirus išimti iš sultinio ir dar šilta (= kol vyniotinis dar yra šiltas) lengvai paslegti. DLKT

(17) „Dabar, - sako Elvidijus, - aš jau nebejaučiu kančios, tik mažam (= kai buvau mažas) man būdavo baisios depresijos. Dabar to nebeliko. Aš turiu vilti." DLKT

(18) Kaipgi? Šitoks artimas žmogus pasimirè. Ir šitiek mažai jam gyvam (= kol jis buvo gyvas) buvo širdies suspèta parodyti. DLKT

(19) Svarbiausias vèliu valgis - gaidys. Jị virdavo su kruopomis. Palikdavo tik skiauterę, kad ir numiręs (= kai bus numiręs) gaidys giedotu, linksmintu. DLKT

614t), sudurtiniu tariniu (žr. Jablonskis 1928/1957: 455), suvestiniu papildiniu (žr. Jablonskis 1928/1957: 472t), sudètinio tarinio vardine dalimi (žr. Balkevičius 1963: 119t), suvestinio papildinio predikatiniu dèmeniu (žr. Labutis 1998: 277t) arba sudètiniu papildiniu (žr. Labutis 1998: 276t). Tik kai kurie autoriai nedaro skirtumo tarp veiksnio ir papildinio predikatyvų ir vadina juos predikatiniu, tarininiu arba predikatyviniu pažyminiu (žr. Ulvydas, red., 1976:437tt; Ambrazas, red., 1996: 490t, 627; Valeckienè 1967: 105tt; Morkūnas, sud., Ambrazas, red., 2008: 536t). Apie tokias traktuotes plačiau žr. Čižik-Prokaševa 2011a: 59tt. 
(20) Jono Pipynès brolis Juozas jaunystëje ${ }^{13}$ (= kai buvo jaunas) buvo padaręs tokiq nuodèmę. DLKT

(21) Jeigu pirštinès susitraukè, galima ištempti. Tereikia jas suvynioti i drègna šluostę, palaikyti porq valandų, o paskui dar drëgnas (= kol pirštinès yra drègnos) užsimauti ir palaukti, kol išdžius. DLKT

(22) Ašišplaukdamas (= kai išplaukiu) moju ranka. (Balkevičius 1963:205)

(23) Nejaugi jūs nemanot, kad atskirai (= kai esate atskirai) dirbdami grašius tegaunat?.. DLKT

\subsection{Priežasties aplinkybiniai antriniai predikatyvai}

Kiek mažiau buvo surinkta priežasties aplinkybinių antrinių predikatyvų: 118 pavyzdžių (jie sudaro 24,9 \% visų pavyzdžių). Visi šie aplinkybiniai predikatyvai perfrazuojami šalutiniais priežasties sakiniais bei žymi priežasties ir padarinio arba teiginio ir jo loginio pagrindo santykius. Dažniausiai jie yra derinami linksniu, skaičiumi ir gimine su pagrindinès predikacijos argumentu (tai gali būti subjektas, kilmininko, naudininko, galininko, įnagininko objektas ir vietininko linksniu reiškiama aplinkybè), ị kurị yra orientuoti (žr. sakinius 24, 25, 27-30), kartais tik skaičiumi ir gimine (žr. sakini 26), o kartais yra reiškiami nelinksniuojama forma (žr. sakinius 31, 32):

(24) Visa apylinke gerbe Motieju kaip gabu meistrq (= nes jis buvo gabus meistras). (Ambrazas, red., 1996: 627)

(25) Laimé, kad tokios miglos mieste, - taré vaistininkas, - tai niekas mūsu ir nematys. Nepatogu gi man, kaip mirusiam (= nes esu laikomas mirusiu), po miesta vaikštinèti... DLKT

(26) Kad įkaitau bebègdamas (= nes bėgau), net prakaitas išmušè. (U1vydas, red., 1976: 534)

(27) Eik trobon, sušalsi pusnuogis (= nes esi neapsirengęs). (Ulvydas, red., 1976: 439)

(28) Išeities ieškok, o ne pabaigos. - Dana, sakau tau kaip motinai (= nes esi motina), aš nebenoriu gyventi, - teberaudojo ant peties Živilè. DLKT

(29) Berniukas peršalęs (= nes jis peršalo) susirgo. (Balkevičius 1963:223)

(30) Ir, žinoma, abi būdamos mamos (= nes abi esame mamos), negalime pamiršti apie artëjančius mokslo metus: kaip jie atrodo Vokietijoje? (http://www.verslimama.lt/lina-ever-berlyne-nera-pinigu-kulto-2017-08-17/)

(31) Akys pavargo bežiūrint (= nuo žiūrèjimo). (Balkevičius 1963:223)

(32) Mes gavome nuo jo avele bičiuliautinai (= nes esame jo bičiuliai). (Ulvydas, red. 1971: 528)

${ }_{13}$ Plačiau apie laisvuosius antrinius prediaktyvus, reiškiamus vietininko linksniu žr. ČižikProkaševa 2010a: 146t. 


\subsection{Nuolaidos aplinkybiniai antriniai predikatyvai}

Dar mažiau buvo surinkta nuolaidos aplinkybinių antrinių predikatyvų: 85 pavyzdžiai (jie sudaro 18 \% visų pavyzdžių). Visi šie aplinkybiniai predikatyvai perfrazuojami šalutiniais nuolaidos sakiniais ir žymi tokią veiksmų ar reiškinių priešpriešą, kai vienas iš jų vyksta, nors kitas sudaro jam nepalankias sąlygas. Dažniausiai jie yra derinami linksniu, skaičiumi ir gimine su pagrindinès predikacijos argumentu (tai gali būti subjektas, kilmininko, naudininko, galininko, įnagininko objektas ir vietininko linksniu reiškiama aplinkybè), ị kurị yra orientuoti (žr. sakinius 33, 36-40), dažnai yra reiškiami ir nederinamosiomis konstrukcijomis (žr. sakinius 34, 35):

(33) Ieško nepametęs (= nors nepametè). (Ulvydas, red., 1976: 537)

(34) Košè ir be sviesto (= nors yra be sviesto) kartais gera, bet su sviestu geresne. DLKT

(35) O pas mus pašokęs iš lovos ir be kelniu (= nors esi be kelnių) gali pas kaimyna pasibelsti. DLKT

(36) Mes, jauni (= nors ir esame jauni), ir tai ne karta pagalvodavome, kad neištversim. (Balkevičius 1963: 438)

(37) Jis ilgai tylëjo. Gal papasakoti jai? Papasakoti apie Babs, apie vargšele Moli, apie save, papasakoti apie tuos slogius ir beprasmius dalykus, kurių net girtas (= nors būtų girtas) neišpasakojo patiems seniausiems draugams? DLKT

(38) Dabar kraujas liejasi tik iš nosių. Bet net mušami (= nors esame mušami) neverkiam. Tik garsiai rèkiam, garsiai. DLKT

(39) Žmona nebeskleidè neigiamu emocijų ir jų santykiai pagerëjo. Pamažu vyras pradëjo galvoti, kam tada gerti, jeigu ir blaiviam gerai? (http:// blog.apiesantykiuskitaip.lt/4-vyro-zaizdos-ir-kaip-moteris-gali-padeti-joms-gyti/)

(40) Sakoma, net negydoma (= nors ji būtų negydoma) sloga praeina per savaite. (https://www.zmones.lt/naujiena/tik-sloga-arsinusitas.8034e0c8-9adf-11e8-9f90-aa000054c883)

\subsection{Sąlygos aplinkybiniai antriniai predikatyvai}

Dar mažiau buvo surinkta sąlygos aplinkybiniu antrinių predikatyvų: 60 pavyzdžiu (jie sudaro 12,7 \% visų pavyzdžių). Visi šie aplinkybiniai predikatyvai perfrazuojami šalutiniais sąlygos sakiniais ir jais nusakomos sąlygos, reikalingos arba trukdančios tam, kad būtų iggvendintas pagrindinis veiksmas. Dažniausiai jie yra derinami linksniu, skaičiumi ir gimine su pagrindinès predikacijos argumentu (tai gali būti subjektas, kilmininko, naudininko, įnagininko objektas), ị kurị yra orientuoti (žr. sakinius 43-45, 47), kartais tik skaičiumi ir gimine (žr. sakinị 41), dažnai yra reiškiami nelinksniuojama 
forma (žr. sakinius 46, 48, 49), o kartais yra reiškiami nederinamosiomis konstrukcijomis (žr. sakini 42):

(41) Ant žemès sèdèdamas (= jei sèdi ant žemès), kur nukrisi? (Ulvydas, red., 1976: 535)

(42) Pašok saldę, gausi papirosą, - pasiūlè plikai kirptas jaunuolis, mūvintis kareiviškas galife kelnes. - Duosi du? - sukruto neūžauga ir pasalūniškai nusišypsojo. - Gausi du, tik šok be kelniu (= jei šoksi be kelniu), - ir susijuoke. DLKT

(43) Kuo vaikai išaugs nebaudžiami (= jei nebus baudžiami). (Ulvydas, red., 1976: 535)

(44) Kaip gyvam būti numirusiam (= jei esi miręs)? DLKT

(45) Menkas malonumas basam (= jei esi basas) žengti akmenuotu ledinio upelio dugnu. DLKT

(46) Pirma Kalèdų dieną, dar nespëjus pasiekti malkų kitam upès krante, pakilo pūga. Grįžti tuščiom ( = jei nieko neturi) negalima, gaila. DLKT

(47) Nevalgęs (= jei nieko nevalgei) sotus nebūsi. (Balkevičius 1963:224)

(48) Gabrielius pačiuose pasąmonès pakraščiuose miglotai suvokè: kiekvienas tų žmonių atskirai (= jei jie yra atskirti) neturi jokio savo ritmo. Tačiau visi kartu, tapę minia arba mase, jie ümai užgrojo negirdètai įtaigią ritmo simfoniją. DLKT

(49) Baimëje (= jei bijo) žmogus sunkiau ịveikia kliūtis, greičiau pasimeta. DLKT

\subsection{Tikslo aplinkybiniai antriniai predikatyvai}

Visai mažai buvo surinkta tikslo aplinkybinių antrinių predikatyvų: tik 14 pavyzdžių (jie sudaro $3 \%$ visų pavyzdžių). Primenu, kad tikslo aplinkybinius antrinius predikatyvus mini tik lietuvių kalbininkai. E. Schultze-Berndt, N. Himmelmannas kalba apie „numatomus veiksmažodinius depiktyvus“ (angl. prospective deverbal depictives). Jų nuomone, tikslo sakiniai turètų būti laikomi antriniais predikatyvais, nes jie gali aprašyti išankstinę būseną, kurią ketina patirti ar pasiekti pagrindinio sakinio veikëjas, su kuriuo jis kartais būna derinamas skaičiumi ir gimine (žr. Schultze-Berndt, Himmelmann 2004: 104tt). Visi šie aplinkybiniai antriniai predikatyvai perfrazuojami šalutiniais tikslo sakiniais. Dažniausiai tikslo aplinkybiniai antriniai predikatyvai turi priklausomų nuo jų žodžių. Dažniausiai jie yra derinami skaičiumi ir gimine su pagrindinès predikacijos argumentu (tai gali būti subjektas, naudininko ar galininko objektas), i kurị yra orientuoti (žr. sakinius 50, 52, 55), kartais yra reiškiami konstrukcija (žr. sakinius 53, 54), o kartais yra reiškiami nelinksniuojama forma (žr. sakinị 51):

(50) Visq dieną bègiojau, ieškodamas mergaitès tèvų (= norèdamas surasti / kad surasčiau mergaitės tévus). (Ulvydas, red., 1976: 538) 
(51) Jums nereikètu trankytis taip toli, ieškant geresnio ūkio (= norint surasti / kad surastumète geresni ūkị). (Ulvydas, red., 1976: 538)

(52) 1871 ir $1875 \mathrm{~m}$. Vilniuje streikavo tabako fabriko darbininkai, reikalaudami padidinti darbo užmokestị (= norèdami gauti / kad gautu didesnị darbo užmokestị). (Balkevičius 1963: 232)

(53) Buоžei mažametis reikalingas kaip pigi darbo jẹga (= kad būtų pigi darbo jèga). (Balkevičius 1963: 124)

(54) Rašydamas apie germanus, sako, kad ,jie renka rankomis dumbla, atseit durpes, džiovina ji, naudodamiesi daugiau veju negu saule, ir išdžiovinta vartoja kaip kurq (= kad išdžiovintą vartotų kaip kurą) valgiui gaminti ir nuo šiaurès vëjo nušiurpusiam kūnui šildytis“. DLKT

(55) Čia, sveikatos ieškodamas (= norėdamas surasti / kad surastų sveikatą), pažadëjau visq vasarq išbūti... (Balkevičius 1963: 233)

Apibendrinti aplinkybinių antrinių predikatyvų vartojimo atvejai pateikiami 1 diagramoje.

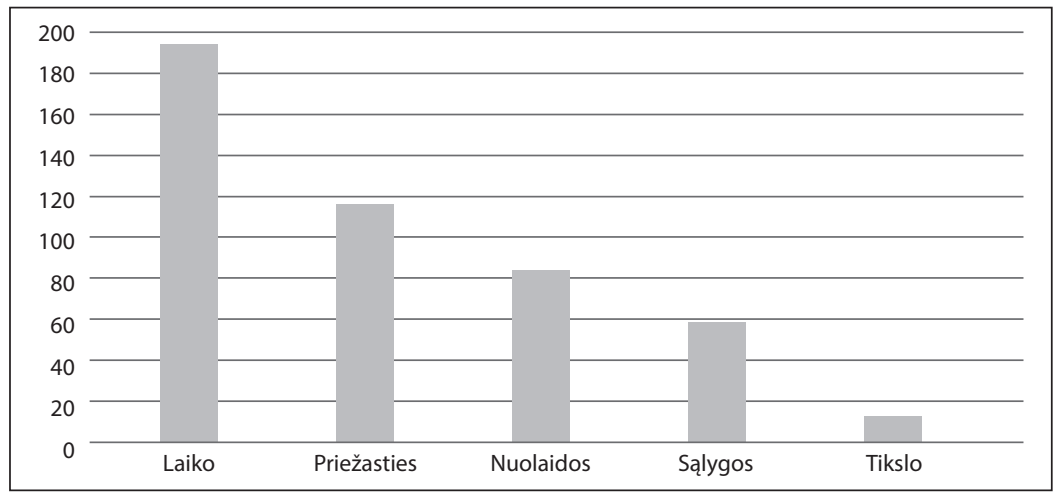

1 diagrama. Aplinkybinių antrinių predikatyvų reikšmės

\section{Aplinkybinių antrinių predikatyvų žymėjimas lietuvių kalboje}

Vieno tyrimo metu (žr. Čižik-Prokaševa 2010a) buvo nustatyta, kad lietuviu kalboje vartojami ne tik tipiniai sintaksiniai (derinamieji) laisvieji antriniai predikatyvai, bet ir semantiniai laisvieji antriniai predikatyvai, kadangi derinamasis linksnis laikytinas tipiniu depiktyvų raiškos būdu, bet ne būtina sąlyga, nes esama ir tokių antrinès predikacijos atvejų, kai antrinis predikatyvas derinamas tik skaičiumi ir gimine arba reiškiamas nelinksniuojama forma. Ir sintaksinių, ir semantinių laisvųjų antrinių predikatyvų atveju svarbiausia yra jų 
semantinè sąsaja su subjektu, objektu ar aplinkybe (kitaip tariant, konceptuali sąsaja su referentu, tai, kas apibūdinama - veiksmažodis ar jo argumentas), o ne antrinio predikatyvo derinimas ar nederinimas linksniu su veiksmažodžio argumentu, kas visu pirma priklauso nuo semantikos.

To tyrimo metu daugiausia buvo surinkta pavyzdžiu su depiktyvais, išreikštais būdvardžiais ir dalyviais, kiek mažiau - su depiktyvais, išreikštais konstrukcija kaip + daiktavardis / būdvardis ir vien daiktavardžiais, dar mažiau - su išreikštais įvardžiais ir padalyviais, mažiausiai - su skaitvardžiais, daiktavardinèmis ir prielinksninemis konstrukcijomis. Buvo sudaryta tokia kalbos dalių, kuriomis reiškiami depiktyvai, hierarchiją: BŪDVARDIS $>$ DALYVIS $>$ KAIP + DAIKTAVARDIS / BŨDVARDIS > DAIKTAVARDIS > I VARDIS > PADALYVIS > SKAITVARDIS > DAIKTAVARDINĖ KONSTRUKCIJA > PRIELINKSNINĖ KONSTRUKCIJA ir nustatyta, kad lietuvių kalboje depiktyvai dažniausiai reiškiami ne tik būdvardžiais bei dalyviais, bet ir daiktavardžiais bei konstrukcijomis kaip + daiktavardis.

Dabar panagrinèkime, kuo lietuviu kalboje yra reiškiami aplinkybiniai antriniai predikatyvai, ar jų žymëjimas kiek nors skiriasi nuo depiktyvų (siaurąja prasme) žymëjimo, jei taip, tai kuo?

Lietuvių kalboje aplinkybiniai antriniai predikatyvai reiškiami įvairiomis kalbos dalimis ir ịvairiomis konstrukcijomis. Ir vienų, ir kitu galima išskirti po septynis atvejus.

\subsection{Aplinkybiniai antriniai predikatyvai, išreikšti tam tikra kalbos dalimi}

\subsubsection{Aplinkybiniai antriniai predikatyvai, išreikšti būdvardžiu}

Daugiausiai pavyzdžių buvo surinkta su aplinkybiniais antriniais predikatyvais, kurie yra išreikšti būdvardžiais: 51 pavyzdys (jie sudaro 21,3 \% aptariamų pavyzdžių). Būdvardžiai ir būdvardiniai junginiai kalbininkų laikomi prototipiniais depiktyvais. Ne išimtis ir aplinkybiniai antriniai predikatyvai. Tokiais atvejais aplinkybinis antrinis predikatyvas linksniu, skaičiumi ir gimine yra derinamas su pagrindinès predikacijos argumentu, ị kurị yra orientuotas. Jis gali būti ịvairių linksnių: vardininko (žr. sakinius 60, 62), kilmininko (žr. sakinị 57), naudininko (žr. sakinius 56, 61), galininko (žr. sakinị 58) ir įnagininko (žr. sakini 59), vienaskaitos (žr. sakinius 56-60, 62) ar daugiskaitos (žr. sakinị 61), vyriškosios giminès (žr. sakinius 56-61) arba moteriškosios (žr. sakinį 62):

(56) Visi, ypač jaunimas, dega sužinoti, kas žandarams ịkišo Pali su Jonu. Rengiasi tokiam gyvam kaili nunerti. DLKT

(57) Ir tavęs nebūtu ìileidusi tokio purvino. (Šukys 1998: 119)

(58) Aš tave jaunq lankydavau. (Ambrazas, red., 1996: 627)

(59) Su juo girtu nesusikalbèsi. (Labutis 1992: 53t) 
(60) Nepatiko man toji flosofine logikos pirmoji paskaita. I antraja paskaita neatvykau. Aš, matyt, iš prigimties daugiau linkęs prie konkretumo. Vedžiau jaunas - jau antrame kurse studijavau uždarbiaudamas pamokomis. DLKT

(61) Tèvas galëjo šiaip taip išmaitinti šeima pupomis, sèlenomis, visokiais žalesiais, laukiniais obuoliais ir kartais nutvertomis riebaly atliekomis, bet visu buvo tvirta nuomoné, kad tikintiesiems nedera vaikščioti i bažnyčiq basiems. DLKT

(62) Saldi ši arbata neskani. (Nichols 1978b: 115)

\subsubsection{Aplinkybiniai antriniai predikatyvai, išreikšti neveikiamosios rūšies dalyviu}

Dalyvinių depiktyvų sintaksinès ir semantinės savybės yra tokios pat, kaip ir būdvardinių. Dèl veikiamosios rūšies laisvųjų antrinių predikatyvų neabejojama, o neveikiamosios rūšies dalyviai lietuvių kalbininkų nebuvo laikomi depiktyvais (tiksliau tarininiais pažyminiais), o laikomi aplinkybemis, manoma, kad jie turi ryškesnị antraeilio veiksmo reikšmès atspalvị (žr. Valeckienė 1967: 110, Sirtautas, Grenda 1988:91). Iš tikrųjų ne visi neveikiamosios rūšies dalyviai gali būti laikomi antriniais predikatyvais, bet tie, kurie reiškia patiriamą būseną ir kartu teikia papildomas semantines sąlygos, nuolaidos, priežasties ar laiko nuorodas, bei yra derinami su pagrindinès predikacijos argumentu linksniu, skaičiumi ir gimine, turètų būti laikomi aplinkybiniais antriniais predikatyvais $^{14}$. Pavyzdžiui, sakinyje Vaikas verkè lupamas. (Balkevičius 1963: 223) neveikiamosios rūšies dalyvis nurodo ne veiksmo būdą kaip verkẻ vaikas, o šio veiksmo priežastį: verkè, nes buvo lupamas, o kartu ir nuorodą, kas patyrè šią būseną. Pavyzdžių su aplinkybiniais antriniais predikatyvais, kurie yra išreikšti neveikiamosios rūšies dalyviais, buvo surinkta kiek mažiau nei pavyzdžiu su būdvardžiais: 45 pavyzdžiai (jie sudaro 18,8 \% pavyzdžių). Toks aplinkybinis antrinis predikatyvas gali būti išreikštas esamojo laiko neveikiamosios rūšies dalyviais (žr. sakinius 63-66) ir būtojo kartinio laiko neveikiamosios rūšies dalyviais (žr. sakinius 67-70). Kaip jau buvo minèta, dalyvinis aplinkybinis antrinis predikatyvas linksniu, skaičiumi ir gimine yra derinamas su pagrindinès predikacijos argumentu, ị kurị yra orientuotas. Jis gali būti ịvairių linksnių: vardininko (žr. sakinius 63-66, 69-70), kilmininko (žr. sakini 68), galininko (žr. sakinį 67), vienaskaitos (žr. sakinius 64, 66, 67, 70) ar daugiskaitos (žr. sakinius 63, 65, 69), vyriškosios giminès (žr. sakinius 63, 65, 67-69) arba moteriškosios (žr. sakinius 64, 66, 70):

(63) Trys beplakami numirè. (Ulvydas, red., 1976: 540)

(64) Ir kate glostoma uodega kelia. (Balkevičius 1963:223)

${ }^{14}$ Panašios nuomonès ir E. Schultze-Berndt su N. Himmelmannu (2004: 98tt). 
(65) Apgailestaujame dèl aklos puikybès, kada patys save girdavome. Dabar mušami išmokome atsukti ir kitq skruosta bei melstis už tuos, kurie mus užgaulioja. DLKT

(66) Koja negydoma neišgis. (Balkevičius 1963: 224)

(67) Na, aš jị ir nulupta pažinčiau, - pasigiria Evè. (Valeckienè 1967: 102)

(68) „Manęs nekalto vos nepasodino ị kalëjima, o dar turiu taisyti kažkieno apmaudžias klaidas?" - sakè R. Gintila. DLKT

(69) Tokius lubinus dažnai matome pamiškèse, pakelèse, kur jie patys auga neséti. DLKT

(70) Magdutè palikta gailiai pravirko. (Balkevičius 1963:230)

\subsubsection{Aplinkybiniai antriniai predikatyvai, išreikšti pusdalyviu}

Lietuvių kalbininkai pusdalyviu irgi nelaikè antriniais predikatyvais (žr. Valeckienė 1967: 111, Ambrazas, red., 1996: 490t). Užsienio kalbininkai linkę laikyti pusdalyvius depiktyvais, pvz., J. Nichols (1978a: 330t), E. SchultzeBerndt, N. Himmelmannas (2004: 101tt). V. Čižik-Prokaševa (2010a: 135) irgi linkusi pusdalyvius laikyti depiktyvais. Dar daugiau - kai pusdalyvis teikia papildomas semantines aplinkybines nuorodas, jis turi būti laikomas aplinkybiniu antriniu predikatyvu. Pavyzdžių su aplinkybiniais antriniais predikatyvais, kurie yra išreikšti pusdalyviais, buvo surinkta kiek mažiau nei pavyzdžių su neveikiamosios rūšies dalyviais: 39 pavyzdžiai (jie sudaro 16,3 \% pavyzdžių). Toks aplinkybinis antrinis predikatyvas skaičiumi ir gimine yra derinamas su pagrindinès predikacijos argumentu, ị kurị yra orientuotas. Jis gali būti vienaskaitos (žr. sakinius 71, 72, 74) ar daugiskaitos (žr. sakinius 71, 73), vyriškosios giminès (žr. sakinius 71-73) arba moteriškosios (žr. sakinị 74):

(71) Tèvas muša vaiką mylèdamas, o svetimi nekęsdami. (Ulvydas, red., 1976: 534)

(72) Vaikas bègdamas parpuole. (Balkevičius 1963: 205)

(73) Gyvendami vis kada pasimatysim. (Ulvydas, red., 1976: 535)

(74) Lazdynu pašakniais slenka vagilè lapè, tykodama užsigiedojusio paukštelio. (Balkevičius 1963: 233)

\subsubsection{Aplinkybiniai antriniai predikatyvai, išreikšti daiktavardžiu}

Nemažai pavyzdžių - iš viso 37 pavyzdžiai (jie sudaro 15,5 \% visų pavyzdžių) - buvo surinkta su aplinkybiniais antriniais predikatyvais, kurie yra išreikšti daiktavardžiais. Tokie laisvieji antriniai predikatyvai plačiai žinomi, jie žymi gyvenimo tarpsnị ar nurodo laikiną objekto vaidmenį, būseną ar padėtį. Dažniausiai daiktavardžio aplinkybinis antrinis predikatyvas reiškiamas vietininko linksniu (žr. sakinius 76, 79), rečiau toks aplinkybinis antrinis predikatyvas 
linksniu, skaičiumi ir gimine yra derinamas su pagrindinės predikacijos argumentu, į kurị yra orientuotas. Jis gali būti įvairių linksnių: vardininko (žr. sakinị 75), naudininko (žr. sakinị 77) ir įnagininko (žr. sakinị 78):

(75) Girdejjau, vedei? - Taip, gali pasveikinti. - Kodèl? Gal esi patenkintas gyvenimu šeimoje? - Apie tai seniai svajojau! Tu, viengungis, neịsivaizduoji, kokia laimé: pareini namo pavargęs, piktas, alkanas. O čiajauku, švaru, ant stalo gèlès, garuoja pietūs, šalia žmona, graži, liekna... DLKT

(76) Vaikystëje mačiau daug vargo. (Šukys 1998: 294)

(77) Jūs man, bèdžiui, kąsnelio tokio pavydit.

(78) Sunku gyventi Maskvoje viengungiu.

(79) Vaikystejje jis buvo per liesas, paauglystëje pasidare pernelyg apkūnus, o jaunystëje, palyginti su pro Geležinę uždanga praslystančio Cosmopolitano etalonais, išvis igavo daugybę trūkumų. DLKT

\subsubsection{Aplinkybiniai antriniai predikatyvai, išreikšti veikiamosios rūšies dalyviu}

Kaip jau buvo minèta, dèl veikiamosios rūšies laisvųju antrinių predikatyvų neabejojama, jų sintaksinės ir semantinès savybės yra tokios pat, kaip ir būdvardinių bei daiktavardinių ${ }^{15}$. Buvo surinkti 34 pavyzdžiai (jie sudaro 14,2 \% visų pavyzdžių). Tokie aplinkybiniai antriniai predikatyvai gali būti išreikšti esamojo laiko (žr. sakinius 86, 87) ar būtojo kartinio laiko dalyviais (žr. sakinius 80-85). Jie linksniu, skaičiumi ir gimine yra derinami su pagrindinės predikacijos argumentu, ị kurị yra orientuoti. Jie gali būti ịvairių linksnių: vardininko (žr. sakinius 80, 82-84), naudininko (žr. sakinius 81, 87), galininko (žr. sakinị 85) ir įnagininko (žr. sakinị 86), vienaskaitos (žr. sakinius 80-82, 84-87) ar daugiskaitos (žr. sakinị 83), vyriškosios giminès (žr. sakinius 81-83, 85-87) arba moteriškosios (žr. sakinius 80, 84):

(80) Ir Veronika, bitelès isiklaususi, nutilo, prie kapo prilipusi, lyg nurimo. (Ulvydas, red., 1976: 540)

(81) Tie jam numirusiam prisuko laikrodi, kad eitų. (Valeckienė 1967: 100)

(82) Senelis sustojęs atsigręžè. (Balkevičius 1963: 205)

(83) Pavalgę jaunieji dar kiek pašūkavo. (Balkevičius 1963: 205)

(84) Paleistuve laikè žmonès ir bažnyčia tą, kuri netekëjusi susilaukdavo kūdikio. (Valeckienè 1967: 102)

(85) Jie pardave piena surūgusị. (Nichols 1981: 367)

${ }^{15}$ Dar žr. Schultze-Berndt, Himmelmann 2004: 103 t. 
(86) Ar pastebëjote, kaip jūsu mylima augintine rūpinasi jumis sergančiu? Ji šildo skaudama vieta, lipa ant galvos, šildo pilvą arba kojas? (http:// www.grynas.lt/gamta/ne-visi-gali-laikyti-kate.d?id=42901541)

(87) Žmogui, sergančiam psichikos liga, sunku prisitaikyti kasdieniame gyvenime. $($ http://jnvc.lt/lt/?option=com_k2\&view=item\&layout $=$ item\&id=116)

\subsubsection{Aplinkybiniai antriniai predikatyvai, išreikšti prieveiksmiu}

Ljiljana Šarić (2008b: 27t) siūlo stipriai susijusius su veiksmo dalyviu prieveiksmius laikyti semantiniais depiktyvais, nes ,semantically, no clear-cut distinction can be made between adverbials and depictives". E. Schultze-Berndt ir N. Himmelmannas irgi mano, kad depiktyvų ${ }^{16}$ negalima griežtai atskirti nuo prieveiksmių, kadangi būna tarpinių atvejų. L. Vaičiulytė-Semènienè irgi mano, kad ,antriniai predikatyvai - depiktyvai, rezultatyvai, aplinkybiniai - gali būti reiškiami ne tik linksnio kategoriją turinčiu - paprastai derinamuoju - žodžiu, bet ir prieveiksmiu“ (Vaičiulytė-Semėnienè 2012a: 68), ,drauge, kartu žymimas laisvasis antrinis predikatyvas gali būti ị subjektą, tiesioginị arba netiesiogini objektą orientuotas kiekio depiktyvas arba aplinkybinis predikatyvas“ (Vaičiulytė-Semènienè 2017: 105). Buvo surinkta 19 prieveiksmio aplinkybiniu antrinių predikatyvų pavyzdžių (jie sudaro $8 \%$ visų pavyzdžių):

(88) Žioplys baisiau už impotentą. Taip ir žinok - tuščiom gali nebegrižti. Kaip Dieva myliu, neileisiu! DLKT

(89) Aš paëjëu senuoju plentu tolèliau nuo mokyklos, tolèliau nuo kitu bendrabutiškiu - būry laukti man negerai, būry aš vis pasijuntu ištižus nevykèle -ir stypsau, tikrai nežinodama, važiuos šiandien senuoju plentu mūsų kolūkio mašina ar nevažiuos. DLKT

(90) Kiek gi gali žmogus zuikio uosle gyventi? Tas nepamatytų, tas nenugirstụ, tas neišpasakotų. Išvargęs ir bemiegis lyg nualintas šuva. Tualetan pavieniui išeiti bijai. O ka jau kalbèti apie tolesnius žygius? DLKT

(91) Nebus šalta čebatuose ir basamìnčia. LKŽe

\subsubsection{Aplinkybiniai antriniai predikatyvai, išreikšti padalyviu}

V. Čižik-Prokaševa linkusi antrinius predikatyvus, išreikštus padalyviais, priskirti prie depiktyvų: „tai, kad padalyviai yra nebūtini, veiksmažodžio nereikalaujami, kad jais nurodoma daikto, būtybès būsena vyksta tuo pat metu, kaip ir pagrindinis veiksmas, kad jie yra orientuoti ì pagrindinio predikato argumentą, rodo padalyvių panašumą ị tipinius sintaksinius (derinamuosius)

${ }_{16}$ Priminsiu, kad jie depiktyvus supranta plačiąja prasme. 
antrinius predikatyvus. Be to, jiems būdinga prototipiškiausia depiktyvų būsenos reikšmè" (Čižik-Prokaševa 2010a: 148). Pasakytina dar daugiau: kai kurie padalyvio antriniai predikatyvai laikytini aplinkybiniais antriniais predikatyvais. Surinkta 14 tokių pavyzdžiu (jie sudaro 5,9\% visų pavyzdžių). Aplinkybiniai antriniai predikatyvai gali būti išreikšti esamojo (žr. sakinius 92, 95, 96) ar būtojo kartinio laiko padalyviais (žr. sakinius 93, 94):

(92) Jonienei iki vakaro ir akys ištịso belaukiant. (Balkevičius 1963: 230)

(93) It toki purvyna apsiavus negalima išbristi. (Ulvydas, red., 1976: 537)

(94) Nepadëjus nèr ko kasti. (Ulvydas, red., 1976: 535)

(95) Grižztant namo, man saule kepino nugara. (Ulvydas, red., 1976: 533)

(96) Niekas nemate jo mirštant. (Šukys 1998: 120)

Aplinkybinių antrinių predikatyvų, išreikštų tam tikra kalbos dalimi, surinkta 239 atvejai. Apibendrinti vartojimo atvejai pateikiami 2 diagramoje.

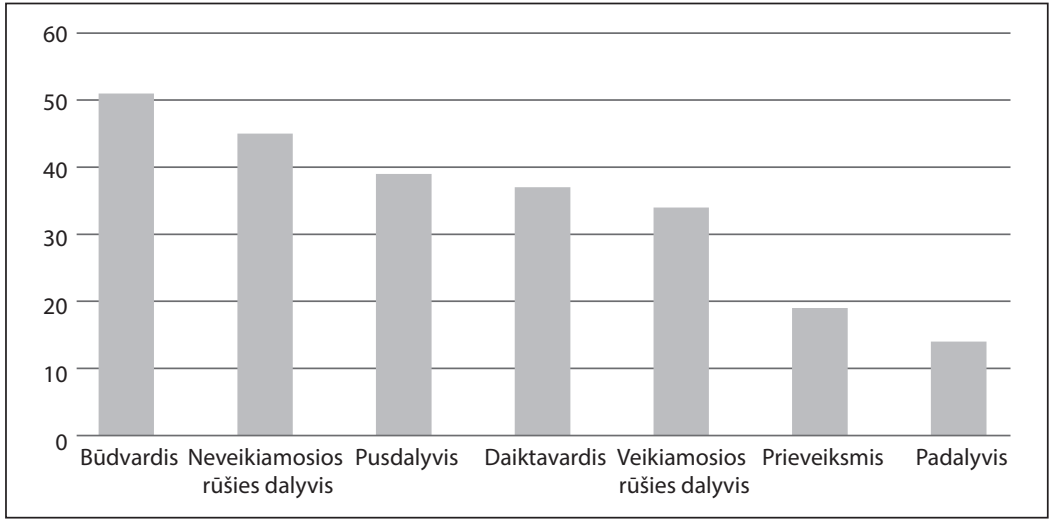

2 diagrama. Aplinkybinių antrinių predikatyvų išraiška kalbos dalimis

\subsection{Aplinkybiniai antriniai predikatyvai, išreikšti tam tikra konstrukcija}

\subsubsection{Aplinkybiniai antriniai predikatyvai, išreikšti konstrukcija kaip + daiktavardis / būdvardis / dalyvis}

Laisvaisiais antriniai predikatyvais laikomos tik tokios konstrukcijos su kaip, kurios nereiškia lyginimo ir kurios yra susijusios su sakinio predikatu ir su vienu iš jo argumentu (dar žr. Čižik-Prokaševa 2010a: 137). Buvo surinkti 55 pavyzdžiai (jie sudaro 23,2 \% visų aptariamų pavyzdžių). Dažniausiai tokios konstrukcijos yra reiškiamos konstrukcijomis kaip + daiktavardis 
(žr. sakinius 97-101), rečiau konstrukcijomis kaip + būdvardis (žr. sakinius 102-104), dar rečiau - konstrukcijomis kaip + dalyvis (žr. sakinius 100, 105). Jie gali nurodyti ị įvairius pagrindinio predikato argumentus: subjektą (žr. sakinius 100, 104), tiesioginị objektą (žr. sakinius 98, 103, 105) arba netiesioginị objektą (žr. sakinius 97, 98, 101, 102) ir yra su juo derinami linksniu, gimine, skaičiumi:

(97) Joms, kaip giminèms, reikètų pranešti apie Povilo mirtį... (Žukauskaitė 1961: 251)

(98) Visi mane, kaip seneli, gerbs. (Žukauskaitė 1961:251)

(99) Mykolo, kaip naujoko, dar niekas nepažinojo, ir jis iejo j salę laisvai. (Žukauskaite 1961:251)

(100) Prasidejus karo pabègèliu emigracijai ị įvairias šalis, Penčyla, kaip pagyvenęs ir viengungis, nesitikejo JAV vizos. DLKT

(101) Taip pat ir jųdvieju sūneliai jai, kaip motinai, buvo artimesni negu jam. DLKT

(102) Man, žinoma, kaip svetimam ir mažam, visų daugiausia kliūdavo. (Balkevičius 1963: 438)

(103) Dèdę, kaip seniausiq, mūsų sūdžia pastatysime. (Žukauskaitè 1961: 251)

(104) Kitos trobos, kaip nereikalingos, buvo nuverstos kurui. (Balkevičius 1963: 183)

(105) Nuo to karto, kaip nesutinkančius tarp savęs, rugius žmonès sëja rudeni, o avižas ir miežius - pavasarị. (Balkevičius 1963: 183)

\subsubsection{Aplinkybiniai antriniai predikatyvai, išreikšti konstrukcija dar + daiktavardis / būdvardis / dalyvis / konstrukcija su būdamas}

Laisvaisiais antriniai predikatyvais laikomos ir konstrukcijos su dar. J. Nichols nuomone, rusų kalbos ešče ,dar' yra tam tikros konstrukcijos gramatinis rodiklis, o ne visavertis semantinis elementas, kad jis traktuotinas kaip predikatinès vardažodinès konstrukcijos gramatinis laiko rodiklis (žr. Nichols 1982: 339). L. Vaičiulytė-Semėnienè irgi mano, kad gramatiniai rodikliai dar, jau rodo žodžio depiktyvinę funkciją ir gali padètį depiktyvą atskirti nuo kitų gramatinių funkcijų (žr. Vaičiulytė-Semènienè 2007b: 123) ${ }^{17}$. Buvo surinktos 54 konstrukcijos su dar, kurios reiškia aplinkybinius antrinius predikatyvus (jie sudaro 22,8 \% visų pavyzdžių). Dažniausiai tokios konstrukcijos yra reiškiamos konstrukcijomis dar + daiktavardis (žr. sakinius 106-108) arba konstrukcijomis dar + būdvardis (žr. sakinius 109-111), kartais - konstrukcijomis dar + dalyvis (žr. sakinius 112-113), įmanoma ir sudètinè konstrukcija dar + būdamas +

17 Daugiau apie tokius rodiklius žr. Schultze-Berndt 2002, Himmelmann, Schultze-Berndt 2005: 65t, Bucheli Berger 2005: 158t. 
būdvardis (žr. sakinị 114). Jie gali nurodyti ị ịvairius pagrindinio predikato argumentus: subjektą (žr. sakinius 106-108, 114), tiesioginį objektą (žr. sakinius 109, 111-113) arba netiesioginị objektą (žr. sakinị 110) ir yra dažniausiai su juo derinami linksniu, gimine, skaičiumi (žr. sakinius 106, 108-113). Kartais konstrukcija dar + daiktavardis reiškiama daiktavardžio vietininku (žr. sakinị 107):

(106) Dar vaikas jis neteko abiejų kojų. (vertimas iš Hentschel 2008: 111)

(107) Tèvas niekam nesišypsodavo. Paranojikas. Neapkentè ir nelaukè meilès. Dar jaunystëje išsižadëjo tèvų. Ittarinëjo kiekvieną. DLKT

(108) Aš laikiau kadaise, dar gimnazistas, du balandžius. (Balkevičius 1963: 242)

(109) Kai ligoniui skubiai prireikè kraujotakos skysčio, maitinančio audinius, Julija dave savojo, nes jų kraujo grupés buvo tos pačios. "Pati dar šilta nunešiau ị operacinę", - šypsojosi miela moteris. DLKT

(110) Grožinès literatūros leidykla vis tiek jo neišleis, oficialioji kritika vis tiek nepripažins, nes literatūros istorijos ketvirtame tome jam, dar gyvam, jau buvo paskelbtas mirties nuosprendis. DLKT

(111) Skalbiant negalima trinti. Nuspausti juos reikia tarp rankšluosčiu ir dar drègnus gerai iššukuoti šepečiu. DLKT

(112) Jonas skaitè knyga dar neįrišta. (Holvoet 2003: 70)

(113) „Zigmantèlis“ buvo jaunystès laiku draugas Skirgaila. Tai jo dar neišdžiūvusị portretą Varnas nešè komisijai, norédamas patekti ị Krokuvos dailès akademiją. DLKT

(114) Neslèpé neapykantos sūnui Medikę pribloškè motinos žodžiai, kad ji dar būdama néščia èmé nekęsti savo įsčiose nešiojamo mažylio. DLKT

\subsubsection{Aplinkybiniai antriniai predikatyvai, išreikšti konstrukcija būdamas + daiktavardis / būdvardis / dalyvis}

L. Vaičiulytė-Semėnienè nustatė, kad lietuvių kalboje „būdamas konstrukcijomis galima reikšti tiek depiktyvinius, tiek aplinkybinius antrinius predikatyvus“ (Vaičiulytė-Semėnienė 2010:6), kad ,pusdalyvinèmis būti konstrukcijomis, sakinyje einančiomis antriniu predikatyvu, reiškiamas laikas, nuolaida, sąlyga bei priežastis“ (ten pat:4). Buvo surinktos 54 konstrukcijos su būdamas, kurios reiškia aplinkybinius antrinius predikatyvus (jie sudaro 22,8 \% visų pavyzdžių). Dažniausiai tokios konstrukcijos yra reiškiamos konstrukcijomis būdamas + daiktavardis (žr. sakinius 115-118) arba konstrukcijomis būdamas + būdvardis (žr. sakinius 121-123), kartais - konstrukcijomis būdamas + dalyvis (žr. sakinius 119, 120). Rastuose pavyzdžiuose visi aplinkybiniai antriniai predikatyvai nurodo ị sakinio subjektą ir yra dažniausiai su juo derinami linksniu, gimine, skaičiumi. Tik kartais konstrukcija būdamas + daiktavardis reiškiama daiktavardžio kilmininku (žr. sakinị 117): 
(115) Būdama vaikas dažnokai matydavau Šiauliu gimnazijoje skelbimus apie dr. J. Šliūpo paskaitas. Temu nepamenu. DLKT

(116) Tačiau ar kas nors, ranka ant širdies padëjęs, gali pasakyti iš tikrųju niekinęs Leva Tolstojų už tai, kad per kara atlikdamas pareiga jis tarnavo artileristu, arba už tai, kad būdamas viengungis jis, kaip didelès potencijos vyras, tenkino savo lytinius poreikius, - ar kas nors remdamasis šiais kaltinimais niekino ji "kaip žemą ir nuodèminga žmogu“? DLKT

(117) Keista, kaip mudu, būdami ịvairiu pažiūru ir būdų, susijungèm... (Ulvydas, red., 1976: 537)

(118) Kartais sutinkame žmones su kuriais nèra apie kq kalbèti, bet jei büdamos mamos sutiksime kita panašaus amžiaus vaika turinčiq mama, tai kalbos tikrai bus ị valias. Sutinkate? (https://www.nevalgiukas.lt/ apie-ka-dazniausiai-kalba-mamos/)

(119) Gerai nusiteikęs, kaip dabar, pajègdavo susitvardyti ir užgniaužti susierzinimą, galbūt atitraukdavo jos dèmeș̣ klausimu arba pasipriešindavo tam nenusakomam pojūčiui pilve ir ramiai žiūrèdavo, kaip ji kišasi. Bet būdamas pavargęs to neatlaikydavo. DLKT

(120) Mokytojas turi būti pyktyje susivaldąs ir būdamas supykęs mokiniu nebaudžia, bet atlieka tai, praëjus pykčiui. DLKT

(121) Jei būdamos nèščios moterys vartojo geležies ir folio rūgšties papildus, tokiu motinu vaiku mirštamumas iki 7 metų amžiaus yra žymiai mažesnis, teigia JAV mokslininkai. (https://www.15min.lt/vardai/ naujiena/lietuva/vaiku-mirstamumas-mazesnis-jei-ju-mamos-vartojo-gelezies-ir-folio-rugsties-papildu-1050-63937)

(122) Geras būdamas neapginsi savęs. Jurbarke jau ir aš pradejjau kumščiuotis, stengiausi save apginti. DLKT

(123) Žmonès sako, kad tai, apie ka moteris galvoja būdama něščia, persiduoda kūdikiui. DLKT

\subsubsection{Aplinkybiniai antriniai predikatyvai, išreikšti konstrukcija ir + būdvardis / dalyvis / padalyvis / konstrukcija su be / konstrukcija su būdamas}

Aplinkybinius antrinius predikatyvus gali reikšti ir konstrukcijos su ir. Buvo surinktos 33 tokios konstrukcijos (jie sudaro 13,9\% visų pavyzdžių). Dažniausiai tokios konstrukcijos yra reiškiamos konstrukcijomis ir + dalyvis (žr. sakinius 124-126), kartais konstrukcijomis ir + būdvardis (žr. sakinius 127, 128) arba konstrukcijomis ir + be + daiktavardis (žr. sakinius 129, 130), įmanoma konstrukcija ir + padalyvis (žr. sakinị 131) ir ir + būdamas + būdvardis (žr. sakinị 132). Jie gali nurodyti ị subjektą (žr. sakinius 124-126, 129, 130, 132) arba netiesioginị objektą (žr. sakinius 127, 128, 131) ir yra dažniausiai su juo derinami linksniu, gimine, skaičiumi (žr. sakinius 124-128, 132): 
(124) Testamentinëje gromatoje jis rašo: „Norèčiau ir numiręs būti jums naudingas..." DLKT

(125) „Sloga - ne liga, praeis ir negydoma“, - dažnai dèl užgulusios nosies negalinčius gerai kvépuoti guodžia aplinkiniai. (https://www.kardiolita. lt/apie-ligas/ausu-nosies-gerkles-ligos/31/kas-mums-trukdo-kvepuoti:61)

(126) Jis ir įsakytas nepadaro. (Balkevičius 1963: 224)

(127) Man ir alkanam nekiltu noras tokios bjaurasties valgyti. (Holvoet, Mikulskas [B]: 6)

(128) Yra daug būdų atsipalaiduoti ir smagiai praleisti laisvalaikị ir blaiviam. (https://www.lrytas.lt/gyvenimo-budas/likimai/2018/11/09/news/ klaipediecio-gyvenimo-kontrastai-nuo-maisto-paiesku-konteineriuose-iki-istaigos-vadovo-posto-8179442/)

(129) Gal per tą suraitytą vamzdeli pamažu čiulpiant rūgstanti broga nebeatrodytu tokia bjauri? Pamegino, ir jam pasirode, kad yra šioks toks skirtumas. Iš bèdos galima nuryti ir be cukraus. DLKT

(130) Ir be šimto atidave. (Balkevičius 1963: 224)

(131) Iš to žodžio visiems ir nenorint juokas kilo. (Ulvydas, red., 1976: 537)

(132) Margot vartojo narkotikus ir būdama nèščia, vaikas gimè neišnešiotas ir mirè. DLKT

\subsubsection{Aplinkybiniai antriniai predikatyvai, išreikšti konstrukcija net + daiktavardis / būdvardis / dalyvis / konstrukcija su be / konstrukcija su būdamas}

Aplinkybinius antrinius predikatyvus gali reikšti ir konstrukcijos su net. Buvo surinktos 28 tokios konstrukcijos (jie sudaro $11,8 \%$ visų pavyzdžių). Dažniausiai tokios konstrukcijos yra reiškiamos konstrukcijomis net + dalyvis (žr. sakinius 133-136), kartais konstrukcijomis net + būdvardis (žr. sakinius 137, 138) arba konstrukcijomis net + daiktavardis (žr. sakinius 139), įmanomos sudètinès konstrukcijos net + be + daiktavardis (žr. sakinị 140) ir net + būdamas + būdvardis (žr. sakinị 141). Jie gali nurodyti ị ịvairius pagrindinio predikato argumentus: subjektą (žr. sakinius 133, 134, 137, 139-141), netiesioginị objektą (žr. sakinius 136, 138) arba aplinkybę (žr. sakinị 135) ir yra dažniausiai su juo derinami linksniu, gimine, skaičiumi (žr. sakinius 133-138, 141):

(133) Priešai net mirę buvo spardomi, niekinami, iš jų büdavo visaip tyčiojamasi. DLKT

(134) Panašiai ir išalkusius asilus galetum pavadinti narsiais: net mušami jie nesiduoda atitraukiami nuo édalo. DLKT

(135) Maskvoje net ištuštẻjusioje įdomu gyventi. (vertimas iš Nichols 1981: 69) 
(136) Ne surišto manęs nesulaikysi. (Šukys 1998: 119)

(137) Ir vaikštinëjau tarp grabų kaip Kalèdu senelis. Aš supratau, kad net girtas negulčiau ne i viena. DLKT

(138) Išvirtų skonis ne ka geresnis kaip vaizdas. Burnoje nuolat jausis šleikščiai salstelëjęs skonis, kuris net alkanam nekels apetito. DLKT

(139) Žinia, narcisizmas nesvetimas kone kiekvienam - su saiku puoselëjamas tai netgi vertingas nūdienos bruoželis, bet poetui jis stačiai būtinas, tai ir gyvasties eliksyras, ir iš numirusiu prikeliantis ženšenis. Suteikia prasmę visa kam, ka bedarytum. Toks žmogus net jaunystëje žino, koks bus jo šlovès formatas sulaukus senatvès. DLKT

(140) Iš baro, kuriame buvo įkalintos, jos spruko net be batu. DLKT

(141) Dabar lengviau atsiduso, nes kuri laika Eglinsko laisvëje nebus. Kiek smūgiu, net būdama nèščia, pakèlè Teresè Eglinskienè, kiek ašaru ir pažeminimo teko iškęsti vaikams... DLKT

\subsubsection{Aplinkybiniai antriniai predikatyvai, išreikšti konstrukcija be + daiktavardis}

Tokios konstrukcijos nekelia abejonių, jos lietuvių kalbininkų buvo visada laikomos antriniais predikatyvais (plačiau žr. Čižik-Prokaševa 2010a: 148tt), užsienio kalbininkų irgi (žr. Schultze-Berndt, Himmelmann 2004: 111). Surinkti 9 be + daiktavardis konstrukciju pavyzdžiai, kurie atlieka aplinkybinio antrinio predikatyvo funkciją (jie sudaro 3,8 \% visų pavyzdžių). Jos gali nurodyti i̇ įvairius pagrindinio predikato argumentus: subjektą (žr. sakinius 143, 144), tiesioginį objektą (žr. sakinị 145) arba netiesioginị objektą (žr. sakinị 142):

(142) Mūsųžmogaus be kelniu nè su botagu neišvarytum žemès arti. DLKT

(143) Milda ir dabar be batu nežengia ne žingsnio, o Vilija eina basa, dailiai iš šalies mesdama dulkètas kojas. DLKT

(144) Be miško suskursta žmogus. (Balkevičius 1963: 224)

(145) Prieš šaldant mèlynes reikia nuplauti, gerai nusausinti. Šaldant be cukraus, uogas sukrèsti ant padèkly 2-2,5 cm storio sluoksniu ir staigiai užšaldyti šaldiklyje 25-30 laipsniu C temperatūroje. DLKT

\subsubsection{Aplinkybiniai antriniai predikatyvai, išreikšti} konstrukcija jau + būdvardis / dalyvis / konstrukcija su būdamas

Kaip jau buvo minèta skyriuje 4.2.2, tokie gramatiniai rodikliai kaip dar, jau rodo žodžio depiktyvinę funkciją ir gali padètį depiktyvą atskirti nuo kitų gramatinių funkcijų. Buvo surasti 4 pavyzdžiai, kai konstrukcija su jau atlieka aplinkybinio antrinio predikatyvo funkciją (jie sudaro 1,7 \% visų pavyzdžių). Viename sakinyje su jau pavartotas būdvardis (žr. sakinị 146), kitame - dalyvis (žr. sakinị 147), kituose dviejuose - konstrukcija būdamas + būdvardis (žr. sakinị 148): 
(146) Miškinị turëjom laimès jau senq pažinti. O koks jis buvo jaunystëje? DLKT

(147) Paauglio jautruma, stropuma, kantrybę, polinkị i rimtus klausimus autorius dažniausiai ne parodo, o nusako, bet viena kita iškalbinga detale (kai Kaziukas sakosi norịs būti ne mokytoju, o šoferiu, kai klejonèse mato dideli vora ar ugni, kai jau mirusiam jam matuojami motinos bateliai, o veliau greitomis siuvamos naginaitès) sukelia stiprų tikrumo ìspūdị ir protestą prieš vaikystès luošinimą. DLKT

(148) Kiekviena moteris atsako už save ir savo vaiką. Jau būdama neeščia ji turi žinoti, ka galès sau leisti. DLKT

Aplinkybinių antrinių predikatyvų, išreikštų tam tikra konstrukcija, surinkta 237 atvejai. Apibendrinti vartojimo atvejai pateikiami 3 diagramoje.

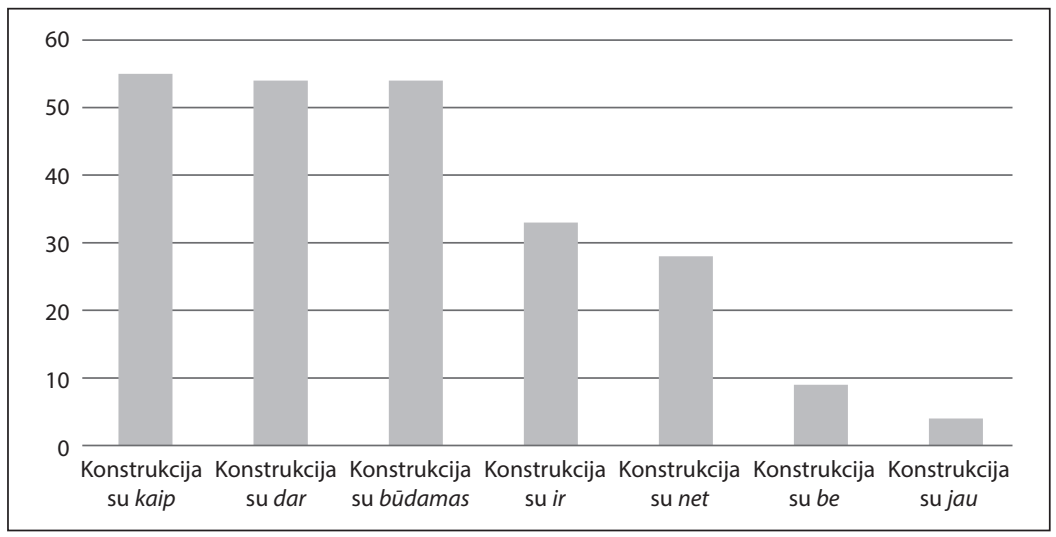

3 diagrama. Aplinkybinių antrinių predikatyvų išraiška konstrukcijomis

\section{Aplinkybinių antrinių predikatyvų vieta sakinyje}

Tyrimas, nustatantis lietuvių kalbos laisvųjų antrinių predikatyvų vietą sakinyje, jau buvo atliktas (žr. Čižik-Prokaševa 2012). Juo metu nustatyta, kad lietuviu kalboje negalima prognozuoti laisvojo antrinio predikatyvo vietos sakinyje pagal tai, ar jis yra depiktyvas (siaurąja prasme), ar jis yra aplinkybinis antrinis predikatyvas (plačiau žr. ten pat: 19tt). Kadangi to tyrimo metu buvo surinkta tik 110 aplinkybinių antrinių predikatyvų pavyzdžių ${ }^{18}$, o šiuo - 473, nuspręsta aną tyrimą patikslinti ir papildyti. Be to, šio tyrimo tikslas - pateikti

${ }_{18}$ O depiktyvų buvo surinkta 947 pavyzdžiai. 
kuo išsamesnę informaciją apie lietuvių kalbos aplinkybinius antrinius predikatyvus. Priminsiu, kad laisvojo antrinio predikatyvo vieta nustatoma atsižvelgiant $\mathfrak{i}$ jo vietos sąsają su pagrindiniu predikatu ir argumentu, į kurị jis nurodo. Galimi šeši modeliai: $\mathbf{A P}+\mathbf{T}+\mathbf{A r}, \mathbf{A r}+\mathbf{A P}+\mathbf{T}, \mathbf{A r}+\mathbf{T}+\mathbf{A P}, \mathbf{T}+\mathbf{A r}+\mathbf{A P}$, $\mathbf{A P}+\mathbf{A r}+\mathbf{T}$ ir $\mathbf{T}+\mathbf{A P}+\mathbf{A r}$ (kur AP - aplinkybinis antrinis predikatyvas, $\mathbf{T}$ - tarinys, sakinio pagrindinis predikatas, $\mathbf{A r}$ - argumentas, ị kurị nurodo aplinkybinis antrinis predikatyas). Ši kartą bandyta trijų narių tvarkos modelius susieti su aplinkybinio antrinio predikatyvo tipu ${ }^{19}$.

1 lentele

Aplinkybinių antrinių predikatyvų tvarkos modeliai

\begin{tabular}{|c|c|c|c|c|c|c|c|}
\hline \multirow{2}{*}{$\begin{array}{c}\text { Aplinkybinio } \\
\text { predikatyvo } \\
\text { tipas }\end{array}$} & \multicolumn{6}{|c|}{ TVARKOS MODELIS } & \multirow[b]{2}{*}{ Iš viso } \\
\hline & $\begin{array}{c}\mathbf{A P}+ \\
\mathbf{T}+\mathbf{A r}\end{array}$ & $\begin{array}{c}\mathrm{Ar}+ \\
\mathrm{AP}+\mathrm{T}\end{array}$ & $\begin{array}{c}\mathbf{A r}+ \\
\mathbf{T}+\mathbf{A P}\end{array}$ & $\begin{array}{c}\mathbf{T}+ \\
\mathbf{A r}+\mathbf{A P}\end{array}$ & $\begin{array}{c}\mathbf{A P}+ \\
\mathbf{A r}+\mathrm{T}\end{array}$ & $\begin{array}{c}\mathbf{T}+ \\
\mathbf{A P}+\mathbf{A r}\end{array}$ & \\
\hline PRIEŽASTIES & 0 & 53 & 23 & 9 & 33 & 0 & $\begin{array}{c}118 \\
(24,9 \%)\end{array}$ \\
\hline LAIKO & 3 & 68 & 32 & 24 & 67 & 2 & $\begin{array}{c}196 \\
(41,4 \%)\end{array}$ \\
\hline SĄLYGOS & 1 & 12 & 14 & 2 & 31 & 0 & $\begin{array}{c}60 \\
(12,7 \%)\end{array}$ \\
\hline NUOLAIDOS & 0 & 38 & 22 & 3 & 22 & 0 & $\begin{array}{c}85 \\
(18 \%) \\
\end{array}$ \\
\hline TIKSLO & 0 & 2 & 9 & 2 & 1 & 0 & $\begin{array}{c}14 \\
(3 \%)\end{array}$ \\
\hline Iš viso & $\begin{array}{c}4 \\
(0,8 \%)\end{array}$ & $\begin{array}{c}173 \\
(36,6 \%)\end{array}$ & $\begin{array}{c}100 \\
(21,1 \%)\end{array}$ & $\begin{array}{c}40 \\
(8,5 \%)\end{array}$ & $\begin{array}{c}154 \\
(32,6 \%)\end{array}$ & $\begin{array}{c}2 \\
(0,4 \%)\end{array}$ & $\begin{array}{c}473 \\
(100 \%)\end{array}$ \\
\hline
\end{tabular}

Gauti tokie rezultatai: dažniausiai vartojamas $\mathbf{A r}+\mathbf{A P}+\mathbf{T}$ modelis, kai aplinkybinis antrinis predikatyvas eina po argumento, ị kurị nurodo, bet prieš pagrindinị predikatą - 173 atvejai (pvz., Santūrus, atsiskyrèliškas, turëjęs savo nuomonę, tačiau labai neafišavęs jos - toksai buvo A. H. Tamsarè, kuriam gimtojo valsčiaus žmonés dar gyvam pastate paminkla (1936) ir kurio varda dažnai kartodavo spauda. DLKT). Jis yra būdingiausias priežasties, laiko ir nuolaidos aplinkybiniams antriniams predikatyvams. Antras pagal dažnumą yra $\mathbf{A P}+\mathbf{A r}+\mathbf{T}$ modelis, kai aplinkybinis antrinis predikatyvas eina prieš argumentą, ị kurị nurodo, ir prieš pagrindinị predikatą - 154 atvejai (pvz., Dar paauglystëje ji pakerëjo indènų dakotų išmintis mokèti tyletti. DLKT). Jis yra būdingiausias sąlygos aplinkybiniams antriniams predikatyvams. Trečias pagal dažnumą yra Ar + T + AP modelis, kai aplinkybinis antrinis predikatyvas eina

19 Ano tyrimo metu tvarka buvo siejama su argumento, ị kuri nurodo antrinis predikatyvas, linksniu (žr. Čižik-Prokaševa 2012: 20tt). 
po argumento, ị kuri nurodo, ir po pagrindinio predikato - 100 atvejų (pvz., Todèl neretai naujagimiai ir vaikai gali ịsijautrinti maistui, kuriuo motina nesaikingai maitinosi büdama nèščia, pavyzdžiui, karvès pienui, citrusiniams vaisiams ir ju sultims, riešutams, medui, šokoladui ir kt. DLKT). Jis yra būdingiausias tikslo aplinkybiniams antriniams predikatyvams. Ketvirtasis pagal dažnumą ir daug rečiau pasitaikantis yra $\mathbf{T}+\mathbf{A r}+\mathbf{A P}$ modelis, kai aplinkybinis antrinis predikatyvas eina po pagrindinio predikato ir po argumento, ị kurị nurodo 40 atvejų (pvz., Koks specialistas? Juk jūs - mokytojas? - Kalbu apie kitq savo specialybę, kurios išmokau dar jaunystëje. Dèdè turbūt nepasakojo? Pogrindžio metais buvau likvidatorius. DLKT). Buvo manoma, $\operatorname{kad} \mathbf{A P}+\mathbf{T}+\mathbf{A r}$ ir $\mathbf{T}+$ $\mathbf{A P}+\mathbf{A r}$ modeliai visai nebūdingi aplinkybiniams antriniams predikatyvams. Pasirodo, jog ir jie įmanomi: buvo rasti $4 \mathbf{A P}+\mathbf{T}+\mathbf{A r}$ modelio sakiniai (pvz., Padrasinti ème smelktis artyn ir kiti. (Balkevičius 1963: 206)) ir 2 T + AP + Ar modelio sakiniai (pvz., Šlakeliu purumo teikiančio losjono ištepk dar drëgnus plaukus. DLKT).

Konstatuotina, kad aplinkybiniai antriniai predikatyvai dažniausiai vartojami prieš tarinị (331 atvejis) ir po argumento, ị kurị nurodo (313 atvejų). Taigi lietuvių kalbos antriniams predikatyvams būdingiausia vieta tikrai yra prieš pagrindinị predikatą, tačiau ne sakinio pradžia, kaip teigiama užsienio literatūroje. Priminsiu, kad 2012 m. tyrimo metu buvo nustatyta, kad depiktyvai dažniausiai eina po tarinio ir po argumento, ị kurị nurodo (žr. Čižik-Prokaševa 2012: 20). Vadinasi, lietuvių kalboje kartais (bet ne visada) antrinio predikatyvo vieta prieš ar po tarinio gali padèti atskirti depiktyvą nuo aplinkybinio antrinio predikatyvo.

\section{Išvados}

1. Lietuvių kalboje skirtini du laisvųjų antrinių predikatyvų tipai: depiktyvai ir aplinkybiniai antriniai predikatyvai. Jie vieni nuo kitu skiriasi ne tik semantika, neigimo aprèptimi, įtraukimu ị pagrindinio sakinio predikaciją (plačiau žr. 2 skyrių), bet kartais ir morfosintakse.

2. Lietuvių kalbos aplinkybiniai antriniai predikatyvai gali būti penkių tipų: laiko, priežasties, nuolaidos, sąlygos ir tikslo. Dažniausiai vartojami laiko $(41,4 \%)$ ir priežasties $(24,9 \%)$ aplinkybiniai antriniai predikatyvai, kiek rečiau nuolaidos (18 \%) ir sąlygos (12,7 \%) aplinkybiniai antriniai predikatyvai, visai mažai (tik $3 \%$ ) pasitaiko tikslo aplinkybinių antrinių predikatyvų (žr. 1 diagramą).

3. Lietuvių kalboje aplinkybiniai antriniai predikatyvai reiškiami ịvairiomis kalbos dalimis ir ịvairiomis konstrukcijomis. Dažniausiai vartojami aplinkybiniai antriniai predikatyvai, išreikšti būdvardžiais (21,3\%), dalyviais (neveikiamosios rūšies - 18,8 \%, veikiamosios - 14,2 \%), pusdalyviais (16,3\%) 
ir daiktavardžiais (15,5\%), rečiau prieveiksmiais (8 \%) ir padalyviais (5,9\%) (žr. 2 diagramą). Iš konstrukcijomis reiškiamų aplinkybinių antrinių predikatyvų dažniausiai vartojamos konstrukcijos su žodžiais kaip $(23,2 \%)$, büdamas (22,8 \%), dar (22,8 \%), ir (13,9\%) bei net (11,8 \%), retai - su be $(3,8 \%)$ ir jau (1,7 \%) (žr. 3 diagramą). Aplinkybinių antrinių predikatyvų, išreikštų kalbos dalimis, surinkta 239, o išreikštų konstrukcijomis - 237. Galima sakyti, kad vartojimas vienodas. O depiktyvai, išreikšti kalbos dalimis, vartojami tris kartus dažniau, nei išreikšti konstrukcijomis ${ }^{20}$. Be to, aplinkybinių antrinių predikatyvų, išreikštų skaitvardžiu ar įvardžiu, nepasitaikè. Vadinasi, aplinkybiniai antriniai predikatyvai nuo depiktyvų šiek tiek skiriasi ir morfosintaksiškai.

4. Nustatyta, kad lietuvių kalboje aplinkybiniai antriniai predikatyvai dažniausiai vartojami prieš tarinị $(\mathbf{A r}+\mathbf{A P}+\mathbf{T}$ ir $\mathbf{A P}+\mathbf{A} \mathbf{r}+\mathbf{T}$ modeliai $)$, o depiktyvai - po tarinio. Vadinasi, kartais laisvojo antrinio predikatyvo vartojimas prieš ar po pagrindinio predikato gali padèti atskirti depiktyvą nuo aplinkybinio antrinio predikatyvo.

\section{Literatūra}

Ambrazas, Vytautas (red.). 1996.

Balkevičius, Jonas. 1963.

Bucheli Berger, Claudia. 2005.

Čižik-Prokaševa, Veslava. 2010a.

Čižik-Prokaševa, Veslava. 2010b.

Čižik-Prokaševa, Veslava. 2011a.

Čižik-Prokaševa, Veslava. 2011b.

Čižik-Prokaševa, Veslava. 2012.

Halliday, Michael A. K. 1967.
Dabartinès lietuviu kalbos gramatika. Vilnius: Mokslo ir enciklopedijų leidybos institutas.

Dabartinès lietuviu kalbos sintaksè. Vilnius: Valstybinè politinès ir mokslinès literatūros leidykla.

Depictive agreement and the development of a depictive marker in Swiss German dialects. Nikolaus P. Himmelmann, Eva Schultze-Berndt (eds.). Secondary predication and Adverbial Modification: The typology of depictives. Oxford University Press, 141-168.

Depiktyvų žymëjimas lietuvių kalboje. Acta Linguistica Lithuanica LXII-LXIII, 128-157.

Laisvieji antriniai predikatyvai. Lietuviu kalba 4, 1-19. Prieiga internete: http://www.lietuviukalba.lt/index.php?id=160

Lietuviu kalbos linksniu hierarchija. Daktaro disertacija. Vilnius: Lietuviu kalbos institutas.

Preliminarus lietuvių kalbos depiktyvų ir kitų į situacijos dalyvị orientuotų antrinių predikatyvų semantinis žemèlapis. Lietuvių kalba 5, 1-17. Prieiga internete: http://www.lietuviukalba.lt/ index.php?id $=199$

Lietuvių kalbos laisvųjų antrinių predikatyvų vieta sakinyje. Baltu Filologija XXI (1), 15-36.

Notes on transitivity and theme in English, part 1. Journal of Linguistics 3, 37-81.

${ }^{20}$ Remiamasi anksčiau minètu V. Čižik-Prokaševos (2010a) tyrimu. 
Hentschel, Gerd. 2008.

Himmelmann, Nikolaus P., Schultze-Berndt, Eva. 2005.

Holvoet, Axel. 2003.

Holvo, Axel. 2009.

Holvoet, Axel, Mikulskas, Rolandas. [A].

Holvoet, Axel, Mikulskas, Rolandas. [B].

Holvoet, Axel, Tamulioniené, Aurelija. 2005.

Irimia, Monica-Alexandrina. 2005.

Jablonskis, Jonas. 1928/1957.

Labutis, Vitas. 1992.

Labutis, Vitas. 1998.

Mikulskas, Rolandas. 2007.

Mikulskas, Rolandas. 2009.

Morkūnas, Kazys (sud.), Ambrazas, Vytautas (red.) 2008.

Nichols, Johanna. 1978a.

Nichols, Johanna. 1978b.

Nichols, Johanna. 1981.

Nichols, Johanna. 1982.
On the classification of (non-resultative) predicative adjuncts. Christoph Schroeder, Gerd Hentschel, Winfried Boeder (eds.). Secondary predicates in Eastern European languages and beyond (Studia Slavica Oldenburgensia 16). Oldenburg: BIS-Verlag, 97-123.

Issues in the syntax and semantics of participant-oriented adjuncts: an introduction. Nikolaus P. Himmelmann, Eva Schultze-Berndt (eds.). Secondary predication and Adverbial Modification: The typology of depictives. Oxford University Press, 1-67.

Laisvieji predikatyvai ir jų sintaksiniai ryšiai. Axel Holvoet, Artūras Judžentis (red.). Sintaksinių ryšiu tyrimai (Lietuvių kalbos gramatikos darbai 1). Vilnius: Lietuvių kalbos institutas, 67-78.

Argumentu hierarchijos ir gramatinès funkcijos. Axel Holvoet, Rolandas Mikulskas (red.). Gramatiniu funkciju prigimtis ir raiška. Vilnius: Vilniaus universitetas, 1-36.

Būtinieji predikatyvai. Prieiga internete: http://old.lki.lt/ LKI_LT/images/Padaliniai/Gramatikos_skyrius/Butinieji\%20 predikatyvai.pdf

Laisvieji antriniai predikatyvai. Prieiga internete: http://old.lki. lt/LKI_LT/images/Padaliniai/Gramatikos_skyrius/Laisvieji\%20 antriniai\%20predikatyvai.pdf

Antriniai predikatyvai. Axel Holvoet, Rolandas Mikulskas (red.). Gramatiniu funkciju tyrimai (Lietuvių kalbos gramatikos darbai 3). Vilnius: Lietuvių kalbos institutas, 117-172.

Types of secondary predication. Toronto Working Papers in Linguistics 25, 20-29.

Linksniai ir prielinksniai. Ju vartojimas mūsų kalboje. Jonas Palionis (sud.). Jonas Jablonskis. Rinktiniai raštai, I tomas. Vilnius: Valstybinè politinès ir mokslinès literatūros leidykla, 549-672.

Rūpinkimès linksnių ir prielinksnių dèstymu mokykloje. A. Šoblinskas (sud.). Lietuvių kalba mokykloje. Kaunas, 40-57. Lietuviu kalbos sintaksé. Vilnius: Vilniaus universiteto leidykla.

Dèl daiktavardinėmis kaip konstrukcijomis reiškiamos antrinès predikacijos pobūdžio. Acta Linguistica Lithuanica 57, 123-155.

Daiktavardinès apozicijos vaidmuo antrinės predikacijos raiškoje. Axel Holvoet, Mikulskas, Rolandas (red.). Gramatiniu funkciju prigimtis ir raiška (Acta Salensia 1). Vilnius: Vilniaus universitetas, Asociacija „Academia Salensis“, 99-124.

Lietuviu kalbos enciklopedija. Vilnius: Mokslo ir enciklopedijų leidybos institutas.

Double dependency? CLS 14, 326-329.

Secondary predicates. Berkeley Linguistic Society 4, 114-127.

Predicate Nominals. A partial surface syntax of Russian. Linquistics 97, Califonia, 1-397.

Prominence, cohesion, and control: object-controlled predicate nominals in Russian. Syntax and Semantics 15, 319-350. 
Schultze-Berndt Eva 2002. Grammaticalized restrictive clitics on adverbials and secondary predicates: evidence from Australian languages. Australian Journal of Linguistics 22, 231-264.

Schultze-Berndt, Eva, Depictive secondary predicates in cross-linguistic perspective. Himmelmann Nikolaus P. 2004.

Sirtautas, Vytautas, Česys Linguistic Typology 8 (1), 59-131.

Grenda. 1988.

Šarić, Ljiljana. 2008a.

Lietuviu kalbos sintaksè. Vilnius: Mokslas.

Secondary predicates in Croatian. Christoph Schroeder, Gerd Hentschel, Winfried Boeder (eds.). Secondary predicates in Eastern European languages and beyond (Studia Slavica Oldenburgensia 16). Oldenburg: BIS-Verlag, 295-326.

Šarić, Ljiljana. 2008b.

Some remarks on resultative constructions in Croatian. Croatica et Slavica Iadertina IV, 23-33.

Šukys, Jonas. 1998.

Lietuviu kalbos linksniai ir prielinksniai: vartosena ir normos. Kaunas: Šviesa.

Ulvydas, Kazys (red.). 1971. Lietuviu kalbos gramatika 2. Morfologija. Vilnius: Mintis.

Ulvydas, Kazys (red.). 1976. Lietuviu kalbos gramatika 3. Sintaksè. Vilnius: Mintis.

Vaičiulytė-Semènienè, Loreta. 2007a.

Vaičiulytė-Semènienè, Loreta. 2007b.

Vaičiulytė-Semènienè, Loreta. 2010.

Vaičiulytė-Semènienè, Loreta. 2012a.

Daiktavardinès kaip konstrukcijos kaip analitinis predikatyvų žymèjimo rodiklis. Acta Linguistica Lithuanica 56, 73-101.

Depiktyvų semantiniai tipai ir jų morfosintaksinis žymèjimas. Baltu Filologiija XVI (1/2), 113-131.

Konstrukciju su büdamas semantika ir morfosintaksès raiškos polinkiai. Lietuviu kalba 4, 1-13. Prieiga internete: http://www. lietuviukalba.lt/index.php/lietuviu-kalba/article/view/20.

Prieveiksminiai antriniai predikatyvai. Baltistica XLVII (1), 51-72.

Vaičiulytė-Semènienè, Loreta. 2012b.

Vaičiulytė-Semènienè, Loreta. 2014.

Vietos antriniai predikatyvai. Baltu Filologiija XXI (1), 73-90.

Laisvųjų rezultatyvų raiška lietuvių kalboje. Baltu Filoloǵija XXIII (1), 105-123.

Valeckienè, Adelè. 1967.

Predikatyvinis pažyminys kaip atskira sakinio dalis. Lietuviu kalbotyros klausimai 9, 97-116.

Winkler, Susanne. 1997. Focus and Secondary Predication (Studies in Generative Grammar 43). Berlin: Werner Hildebrand.

Žukauskaité, Julija. 1961. Kaip vartojimas jungiamuoju žodžiu ir jungtuku. Jonas Kazlauskas, Adelè Laigonaitè, Vincas Urbutis (red.). Dabartine lietuvių kalba. Vilnius: Valstybinė politinès ir mokslinès literatūros leidykla, 217-278.

Veslava Čižik-Prokaševa

Lietuviu kalbos institutas

Bendrines kalbos tyrimo centras

P. Vileišio g. 5, LT-10308 Vilnius, Lietuva

veslava.prokaseva@lki.lt 


\section{KOPSAVILKUMS}

\section{Sekundārie apstākḷu predikatīvi lietuviešu valodā Veslava ČIŽIK-PROKAŠEVA}

Lietuviešu valodā ir izškirami divi brīvo sekundāro predikatīvu tipi: depiktīvi un sekundārie apstākḷu predikatīvi. Tie atšksiras ne tikai ar semantiku, negācijas apjomu, iesaisti teikuma galvenajā predikācijā, bet reizēm arī ar morfosintaksi.

Lietuviešu valodā ir pieci sekundāro apstākḷu predikatīvu tipi: laika, cēloṇa, piel̦āvuma, nosacịjuma un nolūka. Visbiežāk tiek lietoti laika (41,4 \%) un cēloņa $(24,9 \%)$ sekundārie apstākḷu predikatīvi, nedaudz retāk piẹ̦āvuma $(18 \%)$ un nosacijuma $(12,7 \%)$ sekundārie apstākḷ u predikatīvi, pavisam nedaudz (3\%) ir nolūka sekundāro apstākḷu predikatīvu.

Lietuviešu valodā sekundāros apstākḷı predikatīvus izsaka ar dažādām vārdšķirām un dažādām konstrukcijām. Visbiežāk tie izteikti ar īpašības vārdiem (21,3 \%), lokāmajiem divdabjiem (ciešamās kārtas - 18,8 \%, darāmās kārtas - 14,2 \%), daḷẹii lokāmajiem divdabjiem (16,3 \%) un lietvārdiem (15,5 \%), retāk ar apstākḷa vārdiem (8 \%) un nelokāmajiem divdabjiem (5,9 \%).

Visbiežāk lietotās konstrukcijas sekundāro apstākḷu predikatīvu izteikšanai ir ar vārdiem kaip (23,2 \%), büdamas (22,8 \%), dar (22,8 \%), ir (13,9\%) un net (11,8\%), reti - ar be (3,8\%) un jau $(1,7$ \%). Materiālā fiksēti 239 sekundārie apstākḷu predikatīvi, kas izteikti ar vārdšķirām, un 237, kas izteikti ar konstrukcijām. Var sacìt, ka abu lietojums ir līdzvērtīgs.

Savukārt depiktīvi, kas izteikti ar vārdšķirām, tiek lietoti trīsreiz biežāk nekā depiktīvi, kas izteikti ar konstrukcijām. Turklāt sekundārie apstākḷu predikatīvi, kas būtu izteikti ar skaița vārdu vai vietniekvārdu, pētījumā vispār netika fiksēti. Tātad sekundārie apstākḷu predikatīvi no depiktīviem atšksiras arī ar savu morfosintaksi.

Noteikts, ka lietuviešu valodā sekundārie apstākḷu predikatīvi visbiežāk tiek lietoti pirms izteicēja (modȩ̣i $\mathbf{A r}+\mathbf{A P}+\mathbf{T}$ un $\mathbf{A P}+\mathbf{A r}+\mathbf{T})$, kurpretim depiktīvi - pēc izteicēja. Tātad reizēm brīvā sekundārā predikatīva novietojums pirms galvenā predikāta vai pēc var palīdzēt atškirirt depiktīvu no sekundārā apstākḷı predikatīva.

\section{SUMMARY}

\section{Circumstantial Secondary Predicates in Lithuanian Veslava ČIŽIK-PROKAŠEVA}

There are two types of free non-resultative secondary predicates in Lithuanian: depictives and circumstantials. They differ from each other not only in semantics, the scope of negation, inclusion in the predication of the main sentence, but sometimes in morphosyntax.

There are five types of circumstantials in Lithuanian: time, cause, concession, condition and intention. Circumstantials of time $(41,4 \%)$ and cause $(24,9 \%)$ are the most often used, circumstantials of concession (18\%) and condition (12,7\%) are used less, circumstantials of intention are the rarest (only $3 \%$ ).

In Lithuanian circumstantials are expressed by various parts of speech and various constructions. Most examples were collected with circumstantials expressed by adjectives $(21,3 \%)$, participles (passive $-18,8 \%$, active $-14,2 \%$ ), semi-participles $(16,3 \%$ ) and nouns $(15,5 \%)$, less frequently by adverbs $(8 \%)$ and gerunds $(5,9 \%)$. Circumstantials are mostly expressed by constructions with words as (kaip) (23,2\%), being (būdamas) (22,8\%), still, yet (dar) (22,8\%), and (ir) (13,9\%) and even (net) (11,8\%), constructions with without (be) (3,8\%) and already 
(jau) $(1,7 \%)$ are used rarely. The number of circumstantials expressed by the parts of speech is 239 and expressed by constructions - 237. It can be said that the usage of one and the other is the same. Depictives expressed by the parts of speech are used three times more often than expressed by constructions. Furthermore the circumstantials expressed by numerals or pronouns did not occur. Hence morphosyntactically the circumstantials differ somewhat from the depictives.

It was determined that in Lithuanian circumstantials are mostly used before the predicate $($ models $\mathbf{A r}+\mathbf{A P}+\mathbf{T}$ and $\mathbf{A P}+\mathbf{A r}+\mathbf{T})$, while depictives are mostly used after the predicate. Furthermore sometimes the usage of a free non-resultative secondary predicate before or after the main predicate may help to distinguish depictives from circumstantials. 